NBER WORKING PAPER SERIES

\author{
REFINANCING, MONETARY POLICY, AND THE CREDIT CYCLE \\ Gene Amromin \\ Neil Bhutta \\ Benjamin J. Keys \\ Working Paper 28039 \\ http://www.nber.org/papers/w28039
}

\author{
NATIONAL BUREAU OF ECONOMIC RESEARCH \\ 1050 Massachusetts Avenue \\ Cambridge, MA 02138 \\ October 2020
}

The views expressed herein are those of the authors and do not necessarily reflect the views of the National Bureau of Economic Research, the Federal Reserve Board, or the Federal Reserve System.

NBER working papers are circulated for discussion and comment purposes. They have not been peer-reviewed or been subject to the review by the NBER Board of Directors that accompanies official NBER publications.

(C) 2020 by Gene Amromin, Neil Bhutta, and Benjamin J. Keys. All rights reserved. Short sections of text, not to exceed two paragraphs, may be quoted without explicit permission provided that full credit, including $\odot$ notice, is given to the source. 
Refinancing, Monetary Policy, and the Credit Cycle Gene Amromin, Neil Bhutta, and Benjamin J. Keys NBER Working Paper No. 28039

October 2020

JEL No. D12,D14,E50,G21,G51,R31

\begin{abstract}
$\underline{\text { ABSTRACT }}$
We assess the complicated reality of monetary policy transmission through mortgage markets by synthesizing the existing literature on the role of refinancing in policy implementation. After briefly reviewing mortgage market institutions in the U.S. and documenting refinance activity over time, we summarize the links between refinancing and consumption, and describe the frictions impeding the refinancing channel. The paper draws heavily on research emerging from the experience of the financial crisis of 2008-09, as it highlights a combination of market, institutional, and policy-making factors that dulled the transmission mechanism. We conclude with a discussion of potential mortgage market innovations, and the applicability of lessons learned to the ongoing stresses induced by the COVID-19 pandemic.

Gene Amromin

Federal Reserve Bank of Chicago

230 South LaSalle Street

Chicago, IL 60604-1413

gamromin@frbchi.org

Neil Bhutta

Federal Reserve Board

20th and C St N

Stop 149

Washington, DC 20551

neil.bhutta@frb.gov

Benjamin J. Keys

Department of Real Estate

The Wharton School

University of Pennsylvania

432 Vance Hall

3733 Spruce Street

Philadelphia, PA 19104

and NBER

benkeys@wharton.upenn.edu
\end{abstract}




\title{
Refinancing, Monetary Policy, and the Credit Cycle
}

\author{
Gene Amromin, Neil Bhutta, and Benjamin J. Keys ${ }^{1}$
}

\begin{abstract}
We assess the complicated reality of monetary policy transmission through mortgage markets by synthesizing the existing literature on the role of refinancing in policy implementation. After briefly reviewing mortgage market institutions in the U.S. and documenting refinance activity over time, we summarize the links between refinancing and consumption, and describe the frictions impeding the refinancing channel. The paper draws heavily on research emerging from the experience of the financial crisis of 2008-09, as it highlights a combination of market, institutional, and policy-making factors that dulled the transmission mechanism. We conclude with a discussion of potential mortgage market innovations, and the applicability of lessons learned to the ongoing stresses induced by the COVID-19 pandemic.
\end{abstract}

Keywords: mortgage, mortgage rates, refinance, consumption, monetary policy, equity extraction, fixed rate mortgage, adjustable rate mortgage, credit availability, credit constraints, GSE

JEL codes: D12, D14, E50, G21, G51, R31

\section{Introduction}

Monetary policy plays a central role in business cycle management. One of the primary transmission channels for policy actions by the Federal Reserve is to stimulate household consumption by lowering the cost of consumer credit. Although monetary policy accommodation affects all household borrowing rates, from credit cards to auto loans, its potential is arguably greatest in mortgage markets. There is a rather straightforward reason for this: housing constitutes the largest and most widely held asset of U.S. households, with 78 million homeowners owning roughly $\$ 30$ trillion of real estate. This real asset serves as collateral for mortgage loans, making mortgages by far the largest consumer credit market with an aggregate value of approximately $\$ 11$ trillion. Because of the size and wide participation in mortgage markets, influencing the cost of housing credit has the potential to generate sizable income and wealth effects that can be converted into household consumption.

In an idealized setting, a Fed-induced decline in short-term rates results in lower funding costs for financial institutions. These lower costs, in turn, encourages lenders to lower rates they charge to borrowers, thereby expanding the provision of credit. Some of this credit takes the form of home mortgages, which

\footnotetext{
1 DISCLOSURE: The authors are not aware of any affiliations, memberships, funding, or financial holdings that might be perceived as affecting the objectivity of this review. The views expressed here are only those of the authors and do not reflect those of the Federal Reserve Bank of Chicago or of the Board of Governors of the Federal Reserve System.

ACKNOWLEDGEMENTS: We thank Jane Dokko, Lauren Lambie-Hanson, Michael Palumbo, Jonathan Rose, and Shane Sherlund for their comments on an earlier draft of this paper. William Lee provided expert research assistance.
} 
allows homeowners to refinance, thereby replacing their existing debt with new contracts bearing a lower interest rate. The resulting decline in the present value of debt obligations and in the attendant monthly service flows generates both wealth and income effects for borrowers that can be used to support additional household consumption. In this simplified depiction of the easing cycle, the monetary authority transmits stimulus to households through financial intermediaries.

The reality, however, is much more complicated. Monetary policy actions by themselves only affect the cost of credit in the short-term interbank lending market. The extent to which these actions are transmitted to homeowners depends critically on two sets of factors: the pass-through of monetary policy actions to mortgage interest rates, and the ability of households to access mortgage markets. Each of these factors - which can be thought of as the intensive and extensive margins of policy transmission - is determined by a multitude of economic forces. For instance, the ability to lower mortgage rates at the zero lower bound is affected by central bank portfolio choices and by mortgage originator capacity. In the U.S., households' access to refinancing is predicated on their ability to remain creditworthy and on the availability of housing equity. Policymakers' attempts to open refinancing opportunities to borrowers lacking sufficient equity depend on properly aligning the incentives of market participants and on preserving mortgage lending infrastructure.

This paper assesses the reality of these frictions by synthesizing the existing literature on the role of refinancing in monetary policy implementation. Much of the literature we review is based on the experience of the 2008-2009 financial crisis that pushed markets, policy makers, and households to their limits. This experience and the concurrent surge in available data resources helped the profession to formulate better answers to the following key questions: (1) How important is the refinancing channel for transmission of monetary policy to households? (2) What frictions inhibit smooth functioning of this channel and what ex post policy actions help in mitigating them? and (3) What market and policy innovations hold promise for making it function better in the future ${ }^{2}$ As we will argue below, monetary transmission through the housing market was made particularly fraught by a unique combination of a central bank with a limited arsenal of policy tools at the zerolower bound, a multitude of policy-making bodies charting fiscal and housing policy actions with less than complete coordination, and a mortgage market dominated by long-term fixed-rate contracts.

After laying out the institutional environment in section 1, we focus in section 2 on the specifics of transforming monetary policy actions into mortgage rates, both in a typical interest rate environment and under the constraint of the zero lower bound. In section 3, we provide empirical evidence on refinancing and equity extraction activity over the past 30 years to give context for our subsequent discussions. Section 4 centers on both cyclical and behavioral impediments to effective functioning of the refinancing channel, and on the ability of various policy actions to counteract them. We place substantial emphasis on institutional arrangements, private actors' incentives, and regulatory structure, all of which proved to be crucial in inhibiting monetary policy transmission during the financial crisis.

Section 5 assesses the links between refinancing and stimulating household consumption. We consider the role played by the relaxation of liquidity constraints and that of extracting home equity, and we stress heterogeneity in household responses. Sections 6 and 7 look to the future and discuss recent research

\footnotetext{
2 In addition to mortgage servicer and credit bureau databases, researchers have been able to use data from participants in government-sponsored mortgage modification programs, GSEs, public records, investment banks, and financial firm bankruptcy estates.
} 
that highlights the importance of market innovations in designing more robust mortgage contracts and by stressing the limits of the refinancing channel of monetary policy. The lessons learned from the financial crisis are particularly pertinent today, as policymakers face unprecedented economic disruption from the COVID-19 pandemic. Section 8 thus highlights some of the key implications of the pandemic for monetary policy, mortgage markets, and policy choices before concluding with directions for future research.

\section{Institutional Background: The 30-Year Fixed Rate Mortgage and Government Involvement in the U.S. Mortgage Market}

The predominance of the 30-year fixed rate mortgage (FRM) is a defining feature of the U.S. housing finance system, with significant implications for the transmission of monetary policy. Figure 1 indicates that over $90 \%$ of home-purchase mortgage originations in 2018 were 30 -year FRMs, and an additional $4 \%$ were FRMs with terms of at least 15 years. ${ }^{3}$ The main alternatives in the U.S. to these long-term FRMs are fully-amortizing "hybrid" adjustable-rate mortgages (ARMs) with an initial fixed rate typically for the first 3 or 5 years. ${ }^{4}$ There has been some fluctuation over time in the 30-year FRM share, driven in part by changes in the relative prices of different mortgage products (Koijen, Van Hemert, and Van Nieuwerburgh 2009). Still, throughout the two decades depicted in Figure 1, FRMs accounted for the lion's share of outstanding residential mortgages.

The popularity of the 30-year FRM reflects several consumer-friendly features that appeal to risk-averse households (Coulibaly and Li 2009; Campbell and Cocco 2003). It provides nominal payment certainty, relatively low payment size because of the long amortization term, and protection against rising interest rates. At the same time, 30-year FRM borrowers in the U.S. can generally prepay their loan at any time without penalty. ${ }^{5}$ This embedded call option allows households to more easily move, liquidate home equity, and take advantage of declining interest rates by refinancing.

These benefits, though, are not without downsides. First, as we will discuss in more detail below, there are a number of impediments to refinancing, limiting the extent to which households benefit from interest rate declines. Second, because FRMs shift multiple risks related to future interest rate movements to investors, borrowers typically pay a substantial premium relative to ARMs. ${ }^{6}$

The widespread availability of 30-year FRMs in the U.S. stands in stark contrast to most developed countries, where ARMs and shorter-term fixed rate loans tend to prevail (Lea 2010; Campbell 2013; Badarinza, Campbell, and Ramadorai 2018). ${ }^{7}$ The depth of securitization markets may help explain such

\footnotetext{
${ }^{3}$ We provide tables with the statistics for all figures in this paper in the online appendix.

${ }^{4}$ During the housing boom, mortgages with various non-traditional features became prevalent (Dokko, Keys, and Relihan 2019; Amromin et al. 2018).

${ }^{5}$ In many countries, there are sizeable prepayment penalties (Jaffee 2015). The lack of prepayment penalties in the U.S. can be traced to government policy and the institutions that insure and guarantee 30-year FRMs. Most recently, the new Qualified Mortgage rules issued under the Dodd-Frank Act discourage prepayment penalties.

${ }^{6}$ When rates rise, FRM assets lose value as consumers remain in their relatively low-cost mortgage. Yet if rates fall, consumers tend to prepay, forcing investors to reinvest at lower yields.

${ }^{7}$ For example, in the UK, ARMs and hybrid ARMs dominate (Cloyne, Ferreira, and Surrico 2020). In Canada, most mortgages have a term of one, three, or five years, but with a 25 -year a mortization schedule, and the interest rate must then be renegotiated at the end of the term (Allen, Clark, and Houde 2014).
} 
cross-country differences (Fuster and Vickery 2015). Pooling mortgages into mortgage-backed securities (MBS) and selling them in international capital markets avoids the maturity mismatch problem presented when banks hold long-term mortgages funded with short-term deposits. ${ }^{8}$

Demand and institutional factors may also help explain cross-country variation in securitization and FRM use. As Green and Wachter (2005) point out, there may be some path-dependence in the types of loans consumers feel comfortable with. Long-term fixed-rate amortizing contracts were available nationwide in the U.S. since early $20^{\text {th }}$ century (Rose 2019). The Federal Land Bank System and the Joint Stock Land Banks offered 33-year contracts from 1916 onwards, and Building and Loan associations offered 12-year mortgages. Both of these had similar antecedents in Europe. Yet, it was the U.S. government's entry into mortgage markets that made long-term, self-amortizing FRMs a widely adopted alternative to short-term balloon mortgages that precipitated a foreclosure wave during the Great Depression (Green and Wachter 2005). To improve the funding and availability of such loans, the government also created the Federal Housing Administration (FHA) to insure these mortgages and Fannie Mae to issue bonds and purchase FHA-insured FRMs. In the absence of such government intervention, the 30-year FRM may never have caught on in the U.S.

Today, the federal government continues to play a central role in the U.S. housing finance system. Several government agencies such as the FHA and the Veteran's Administration (VA) insure or guarantee many mortgages, including both fixed-rate and adjustable-rate contracts that meet agency-specific size, underwriting, and eligibility requirements. The other key players in housing finance are the governmentsponsored enterprises (GSE) - Fannie Mae and Freddie Mac. Prior to the financial crisis, the GSEs were private institutions that were established and chartered by the Federal government for public policy purposes. The GSEs purchase "conventional" mortgages (i.e. not FHA-or VA-backed) that meet GSE credit standards and loan size limits set by Congress (Conforming Loan Limits), and pool them into "agency MBS" that carry a GSE guarantee against credit risk. ${ }^{9}$ Despite their private status, investors in GSE MBS long perceived the GSE credit guarantee to be as good as a government guarantee, giving the GSEs a funding advantage and allowing them to dominate the market (Frame and White 2005; Passmore 2005; Acharya et al. 2011). This perception became reality during the financial crisis, as the GSEs were bailed out by the government and taken into conservatorship in 2008. Over 10 years later, the GSEs remain under government control.

Figure 2 shows the shares of new loans insured or guaranteed by the GSEs and federal agencies over time. These shares fluctuated dramatically during the housing boom and bust. As the financial crisis deepened and private capital dried up, the mortgage market became extraordinarily dependent on these institutions. A key lesson from this episode is that these institutions can help smooth fluctuations in credit availability over the business cycle, and thus can help transmit accommodative monetary policy to households through the mortgage market (Hurst et al. 2016; Passmore and Sherlund 2019). Moreover, as we will discuss below, the government was able to exploit the wide footprint of these institutions to

\footnotetext{
8 That said, banks do maintain some exposure to long-term FRMs, holding both whole loans and MBS on their balance sheets. Such holdings may not be as risky as traditionally thought, as deposit rates in the U.S. have been shown to be quite sticky rather than a pure floating-rate liability (e.g. Driscoll and Judson 2013). Drechsler, Savov, and Schnabl (2018) attribute this stickiness to banks' market power.

9 Note that the term "agency MBS" can also include Ginnie Mae MBS composed of government-backed loans.
} 
implement large-scale refinancing programs. Such countercyclical benefits have featured prominently in the debate about the future of housing finance in the U.S.

\section{Monetary Policy and Mortgage Rates}

Before turning to our discussion of how changes in mortgage rates affect household balance sheets and spending via mortgage refinancing, we consider the question of whether the Federal Reserve influences the interest rates at which households and firms can borrow. This question has long been studied by economists, but significant progress has been made in recent years using new data and innovative empirical methods.

"Conventional" monetary policy - as opposed to "unconventional" monetary policy, which we will discuss below - entails the Fed changing its target for the federal funds rate (the rate at which banks lend to each other overnight) and trading securities in the open market to achieve that rate. One empirical challenge in identifying the effect of a change in the target rate is that Fed actions generally occur endogenously in response to economic events that themselves could affect interest rates in the economy. For example, during the financial crisis, the Fed aggressively lowered the federal funds rate, and rates on Treasury securities also declined (Figure 3). But the declines in Treasury rates likely reflected both the independent effects of monetary policy as well as increased demand for highly liquid, risk-free assets. Another empirical challenge is that markets may anticipate what the Fed will do at their next policy meeting (typically every 8 weeks), especially if Fed officials signal upcoming rate changes through speeches and other communications. Thus, when the Fed officially announces a change to the target federal funds rate, other interest rates may have already moved in anticipation and thus it may appear as though Fed policy had no effect.

In recent years, researchers have addressed these empirical challenges by using high frequency (daily and intra-day) interest rate data and event study designs to help identify the causal effects of monetary policy. Pioneered by Kuttner (2001) and Cochrane and Piazzesi (2002), the key idea in this approach is that the level of various market interest rates just prior to any Fed target rate announcement should fully embed all public information. Thus any sharp change in short-term rates from just before to just after the announcement reflects a policy shock. ${ }^{10}$ In recent work, Nakamura and Steinsson (2018) use this event study approach and estimate that a 100 basis point monetary policy shock is associated with about a 40 basis point change in both nominal and real 10-year Treasury rates. ${ }^{11}$ Moreover, because households tend to prepay their mortgages within the first 10 years, fluctuations in 5-10 year Treasuries have a strong effect on mortgage rates. Gilchrist, Lopez-Salido, and Zakrajsek (2015) estimate that a conventional monetary shock of 10 basis points lowers interest rates on 30-year fixed rate mortgages by about 6 basis points (also see Gertler and Karadi 2015).

\footnotetext{
${ }^{10}$ Cook and Hahn (1989) found that target rate changes during the late 1970's were associated with changes in market rates, but subsequent research failed to find such connections during the 1980's and 1990's. However, as Kuttner (2001) points out, none of these early studies distinguished between anticipated and unanticipated changes to target rates.

11 Nakamura and Steinsson (2018) also examine instantaneous forward rates at various horizons to show that the effect on 10 year Treasury rates reflects changes to expectations for short-term rates in the 3 to 5 years after the policy shock, as opposed to monetary policy having long-run effects on rate expectations. In contrast, Hanson and Stein (2015) find that monetary policy has a substantial effect on the 10-year forward real rate, although they argue this long-run effect likely reflects changes in term premia.
} 
During the financial crisis, the Fed exhausted its conventional tools as the federal funds rate hit the socalled zero lower bound (ZLB) by the end of 2008. Constrained by the ZLB, the Fed was forced to rely on "unconventional" methods of monetary policy to provide further stimulus. These methods include trying to influence expectations of the future path of short-term interest rates ("forward guidance"), and trying to lower longer-term interest rates more directly through large-scale purchases of longer-term assets, including agency MBS. This purchase activity is often referred to as "quantitative easing" or QE.

Prior to the Fed implementation of QE policies, research supported the notion that such an approach could be effective. For example, Bernanke, Reinhart, and Sack (2004) find that shocks to the expected supply of Treasury debt indeed affect Treasury yields. After QE, event-study based evaluations indicate substantive drops in both Treasury and MBS yields immediately after surprise QE announcements of future asset purchases (e.g. Gagnon et al. 2010; Krishnamurthy and Vissing-Jorgensen 2011). ${ }^{12}$ Estimates suggest that QE1, which lasted from late 2008 to early 2010 (see Figure 3), led to declines in MBS yields of about 100 basis points, reflecting the Fed's focus on MBS purchases during QE1. ${ }^{13}$

In addition to affecting Treasury and MBS yields, QE has also been found to have lowered primary market mortgage rates faced by households. It is important to separately test for the effects of QE on primary rates, given that secondary market and primary market rates can diverge (Fuster et al. 2013). DiMaggio, Kermani, and Palmer (2020) test whether QE affected primary mortgage rates by comparing the evolution of rates paid for conforming-size loans - which were most directly affected by QE purchases of agency MBS - versus jumbo (GSE-ineligible) loans, before and after QE. They find that the interest rates on new conforming mortgages dropped by over 50 basis points relative to jumbo loans. ${ }^{14}$ Fuster and Willen (2010) and Hancock and Passmore (2011), using different data and methods, also provide evidence of sharp declines in primary mortgage rates due to $Q E$.

In summary, the available research provides compelling evidence that both conventional and unconventional monetary policy has substantive direct effects on interest rates in the economy, including the mortgage rates faced by households. We next turn to the available evidence on how households respond to declines in mortgage rates.

\section{Mortgage Refinancing and Equity Extraction Over Time}

In order for monetary policy to successfully be transmitted to the household sector, households must exercise their option to refinance. However, transaction costs, such as origination, appraisal, and title fees, as well as taxes, drive a wedge between interest rate changes and refinancing activity. Because of the transaction costs, mortgage rates must drop by enough to justify refinancing.

In addition, for a given drop in interest rates, the benefits of refinancing will vary across households depending on several factors such as their expected time horizon in their home and their marginal tax

\footnotetext{
12 The estimated effects of QE1 are larger than QE2, which may reflect that the earliest QE announcements were the most significant and surprising (Krishnamurthy and Vissing-Jorgensen 2011).

13 The disproportionate effect of MBS purchases on MBS yields reflects a "portfolio balance" effect due to imperfect substitutability between assets of different types and maturities (Brainard and Tobin 1968). For another interesting example of such effects, see D'Amico and King (2013).

${ }^{14}$ To the extent that there were some spillover effects ofQE on interest rates for jumbo mortgages, these difference-in-difference estimates of QE's effect on mortgage rates can be considered conservative.
} 
rate. This heterogeneity implies that not all households would optimally refinance at the same time. Finally, even when the present value of benefits exceeds the transaction costs, households may rationally delay refinancing if further declines in rates are possible.

In a groundbreaking paper, Agarwal et al. (2013) provide the first closed-form optimal refinancing rule, taking into account the various costs and benefits, as well as the option-value of waiting given historical interest rate volatility. Their solution suggests that the interest rate differential required to make refinancing worthwhile typically is 100 basis points or more.

Panel A of Figure 4 shows the fraction of 30-year FRM borrowers that are likely to be "in-the-money" for refinancing, having an interest rate of at least 100 basis points higher than the prevailing average prime offer rate from Freddie Mac's Primary Mortgage Market Survey. The share of likely refinance candidates was elevated in 2002-2003 as mortgage rates dropped below 6 percent for the first time in decades, and peaked in 2012 when rates hit all-time lows, though refinancing frictions (as discussed in Section 4) were quite severe. A caveat to this figure is that not all borrowers can expect to qualify for the prime rate. For some, available rates are likely to be higher; but others may qualify for rates below prime. Data on specific offer rates for different types of borrowers have only recently become available to researchers (see for example Bhutta, Fuster, and Hizmo 2019), with a limited historical time series.

Contemporary mortgage research has also started exploiting panel data from consumer credit agencies. Relative to various loan-level datasets used in many papers, credit data is highly representative and allows researchers to observe all mortgages held by a borrower and to follow borrowers from one mortgage to the next. These attributes are extremely useful for studying refinancing activity.

Panel B uses the FRBNY Consumer Credit Panel/Equifax Data (CCP) to plot annual estimates from 2000 to 2018 of the fraction of homeowners that refinanced their first-lien mortgage, split into the share doing a basic "rate" refinancing, and those doing a "cash-out" refinancing to extract equity. We also plot the fraction of households extracting equity without involving a first-lien refinancing (e.g. drawing on a home equity line of credit). ${ }^{15}$ This graph reveals a sharp spike in 2003 in both types of refinancing. Combined, we estimate that nearly 30 percent of borrowers refinanced. In contrast, in 2012 when mortgage rates dropped to well below 4 percent and refinance incentives were historically high, only about 10 percent of borrowers refinanced without cash out, and very few - just 2.1 percent - did a cash-out refinance.

Panels $C$ and $D$ display propensities of rate and cash-out refinancing by credit score. Panel $C$ shows that whereas the likelihood of rate refinancing jumped in both 2003 and 2012 for higher-score borrowers, lower-score borrowers rarely did a pure rate refinancing. In Panel D, however, lower-score borrowers posted a similar propensity of cash-out refinancing as higher-score borrowers in 2003, and cash-out refinancing was very limited for both groups in 2012. Notably, lower-score borrowers continued to do cash-out refinances at elevated propensities rate through 2006, despite rising interest rates. This pattern may reflect a credit expansion starting in mid-2003 (Justiniano, Primiceri, and Tambalotti 2017), combined with long-running house price growth (Bhutta and Keys, 2016).

Finally, to provide a longer-run perspective on refinancing activity, we turn to data reported by lenders under the Home Mortgage Disclosure Act (HMDA), which contains information on nearly the universe of

\footnotetext{
15 Note that those who refinance their first lien and simultaneously extract equity through a junior lien are included in the cashout refinance category. This analysis draws on the methodology described in Bhutta and Keys (2016)
} 
originated residential mortgages. Figure 5 displays the dollar volume of all refinance originations (cashout and rate refinances cannot be distinguished in these data) on 1-4 family properties each year, as a fraction of total outstanding residential mortgage debt as of the end of the prior year. Here we can see two additional waves of refinancing in 1993 and 1998. These two episodes fell short of the refinancing activity seen in 2003, but exceeded refinancing activity in 2010-2012, despite the historic drop in rates post crisis.

Overall, this section has provided new data on refinancing activity across several episodes of interest rate declines, highlighting that refinancing activity can be weaker than expected for some types of borrowers and at certain points in time. In the next section, we discuss both demand-side and supply-side factors that may impede refinancing activity.

\section{Impediments to Refinancing}

The discussion above highlights that borrowers may not refinance even when rates have fallen and the option is "in the money." In this section, we discuss both demand-side and supply-side factors that can inhibit the refinancing channel of monetary policy.

\section{Behavioral Impediments to Refinancing}

In order to determine whether a household's refinancing choice is optimal, researchers have compared the benefits (in the form of reduced monthly payments) from refinancing at today's interest rate to the transaction costs. In an influential paper, Stanton (1995) explicitly modeled heterogenous transaction costs, and found that mortgage holders often behave as though they face extremely high costs. ${ }^{16}$ Those borrowers who fail to refinance are sometimes referred to in the literature as "ostriches" with their heads in the sand (Green and LaCour-Little 1999), or "woodheads" (Deng and Quigley 2012) who do not react to new information.

Examining the mortgage market in December 2010, Keys, Pope, and Pope (2016) estimate that 20\% of unconstrained households (on the basis of house prices and origination FICO scores) for whom refinancing was optimal (based on the Agarwal et al. 2013 optimal rule) had not done so. This decision was quite costly: Keys et al. (2016) estimate that the median household would have saved $\$ 160$ per month in interest payments, or $\$ 11,500$ in discounted present value terms over the life of the loan. Agarwal, BenDavid \& Yao (2016) and Agarwal, Rosen, and Yao (2019) document mistakes not just of omission, but also of commission: refinancing, but not at the optimal time. They estimate that half of refinancers do so at a rate that was at least 50 basis points from the optimal refi rate.

What can explain suboptimal refinancing behavior? Some research has pointed to a lack of borrower sophistication. For instance, Bucks and Pence (2008) show that a sizeable fraction of borrowers cannot correctly recall the terms of their existing loans. Suboptimal refinancing occurs less frequently among homeowners with higher credit scores, incomes, and education (e.g. Campbell 2006, Keys, Pope \& Pope

16 Even the earliest examinations of MBS performance identified failures of refinancing in both directions, prepayment when rates were too high and failing to refinance when rates fell (see, e.g., Dunn and McConnell 1981). 
2016, Agarwal et al. 2016). ${ }^{17}$ However, as the authors of these studies point out, this evidence is not clear cut because these attributes may also be correlated with a higher likelihood of loan approval. A lack of financial acumen may also result in homeowners underestimating the financial benefit of refinancing. In a field experiment studied by Keys, Pope, and Pope (2016), one-third of those who did not take up the refinancing offer did not think the savings were significant enough, despite no up-front expenses.

Beyond sophistication, research points to several behavioral factors that generate suboptimal refinancing. Andersen et al. (2015) find a role for both inattention, where individuals do not gather necessary information to make a refinance decision, and inertia, where individuals have a psychological cost of acting on information. Johnson et al. (2018) point to mistrust of financial institutions in borrowers' reluctance to accept an "in the money" refinancing offer.

Finally, we note that while studies in this area typically assume that, on a given day, all borrowers face a single prevailing interest rate, recent research shows that there is actually wide dispersion in the rates lenders would offer to prospective borrowers (Bhutta, Fuster, Hizmo 2019; Alexandrov and Kouleyev 2018). Because many borrowers do not shop around effectively and do not seem to appreciate that lenders vary in their pricing (Woodward and Hall 2012; Gurun, Matvos, and Seru 2016; Bhutta, Fuster, and Hizmo 2019), limited access to the best interest ratescould negatively affect refinancing activity, or lead to suboptimal refinancing outcomes.

\section{Cyclical Impediments to the Refinancing Channel}

In a setting dominated by fixed rate mortgage contracts, households need to refinance their existing obligations. Yet, household ability to do so can be severely compromised in recessions. This subsection describes various refinancing frictions in detail and lays the groundwork for a subsequent discussion of policies employed to remedy them.

Refinancing an existing mortgage to obtain better terms or to extract equity requires taking out a new loan contract to replace an existing one. As such, refinancing triggers a new round of underwriting that has traditionally consisted of reviewing a borrower's income and creditworthiness, as well as the value of the underlying collateral. Each of these underwriting criteria has a strong cyclical component, weakening in recessions and strengthening in boom years. Moreover, the stringency of underwriting requirements is procyclical as well, as lenders dealing with cyclical deterioration in loan performance tighten standards on extending new credit.

All of these phenomena played out in the extreme during the Great Recession, and can help explain weak post-crisis refinancing volumes (Figures 4 and 5). Earlier literature, based on the data from the 1980's and 1990's, showed that income constraints, whether measured at the individual household level (Archer et al. 1996) or proxied by local unemployment rate (Pavlov 2001) indeed have an important negative effect on mortgage refinancing. Although all recessions are characterized by job losses, the unemployment rate during the Great Recession reached a peak of 10 percent and an average duration of nearly 40 weeks

\footnotetext{
17 Examining refinancing behavior in Italy, Bajo and Barbi (2018) use unique measures of financial expertise or knowledge (e.g. a degree in finance or economics) to show that take-up of refinancing opportunities is driven by financial sophistication.
} 
(Farber and Valletta 2015), making it exceedingly difficult for affected borrowers to demonstrate their ability to pay back a loan.

Income shocks generated by job loss also put stress on borrowers' ability to service their debt, often leading to outright delinquency. Using data from the 2009 - 2013 PSID surveys, Gerardiet al. (2018) show that job losses have an equivalent effect on mortgage delinquency as a 35 percent decline in home equity. As a practical matter, lenders are generally reluctant to refinance delinquent mortgages, making loan modification the only possible avenue for transmission of stimulus measures. However, since modifications are driven primarily by lender willingness to restructure non-performing debt and by government incentives, as opposed to monetary policy actions per se, we leave them out of the present discussion. ${ }^{18}$

Even when homeowners manage to stay current on their mortgages, income shocks can trigger delinquencies on their other obligations, from student loans to credit cards. These delinquencies have an immediate and lasting effect on credit scores, potentially pushing borrowers outside of lenders' acceptable credit score ranges.

Moreover, recessions are often accompanied by tightening in credit score standards. The evidence from the Great Recession showcases a swift response from both private market investors and governmentbacked mortgage guarantors (GSEs). Starting in April 2008, the GSEs added surcharges for borrowers with credit scores below 740. For instance, a borrower with a credit score of 670 and 20 percent equity faced an additional upfront charge of $2.5 \%$ of the value of the loan. Folding this surcharge into the loan would typically add about 60 basis points to the loan interest rate, reducing benefits of refinancing. ${ }^{19}$

Although on paper GSEs continued to allow origination of mortgages to borrowers with FICO scores as low as 620 , lenders superimposed their own, stricter set of credit conditions. ${ }^{20}$ All told, nearly 70 percent of Fannie Mae-backed mortgages originated between 2008 and 2013 were for borrowers with FICO scores above 750, compared to 36 percent of borrowers in 2007 and 32.4 percent from 1999-2004 (Urban Institute, 2013). In addition, the virtually overnight disappearance of private mortgage securitization markets represented a particularly dramatic supply-side response to the financial crisis. These markets accounted for the lion's share of funding for low FICO score and other risky borrowers, and their collapse left those borrowers with few refinancing options. In general, reductions in mortgage origination capacity have been shown to impair refinancing and drive a wedge between MBS yields and mortgage rates postcrisis (Fuster et al. 2013).

In addition to tightening credit standards, lenders and the GSEs started enforcing ability-to-pay requirements typically measured as share of mortgage payments to income (PTI). Pre-crisis mortgage

\footnotetext{
18 A substantial literature on loan modifications during the Great Recession covers the evolution and take-up of different approaches to modification, the effectiveness of private and government-sponsored programs, and their success in preventing re-default and stimulating consumption. Some of the papers in this literature include: Piskorski, Seru, and Vig (2010), Aga rwal et al. (2011, 2017a), Adelino, Gerardi, and Willen (2013), and Mayer et al. (2014).

${ }^{19}$ As an example, a complete list of 2008 Fannie Mae surcharges, known as loan-level pricing adjustments (LLPA) is available at: https://www.fanniemae.com/content/announcement/0838.pdf.

20 Such lender overlays arose because of "put-back risk." In every mortgage transaction, the originator certifies that the underwriting data, i.e., borrower's income, assets, and house value, are truthful. This certification is known as representations and warranties (R\&W). Any mortgage found to be in violation of its $R \& W$ has to be bought back by the originator who bears all credit losses. In the aftermath of the financial crisis, GSEs conducted aggressive audits for possible R\&W violations for every defaulted loan. As a result, mortgage originators that securitized their loans through the GSEs regarded R\&W as a major liability.
} 
underwriting allowed low-documentation or even no documentation loans (Jiang et al. 2014). As starkly illustrated in Greenwald (2018), even fully-documented loans securitized by the GSEs displayed no meaningful PTI limit. These practices changed quickly with the onset of the financial crisis - full documentation became necessary, and PTI limits (45\% in case of the GSEs) were enforced. Moreover, the Dodd-Frank Act (DFA) stipulated hard PTI bounds and put limits on what constitutes acceptable sources of income. ${ }^{21}$ Taken together, these responses clearly demonstrate how erosion in borrower credit scores and/or income shocks, common in recessions, can either severely curtail the benefits of refinancing or eliminate access to refinancing altogether.

Aside from credit impairment and income losses, insufficient home equity represents a major barrier to borrowers' ability to refinance. Erosion of home equity became a particularly potent friction during the Great Recession, driven both by the magnitude and scope of house price declines and by substantial equity extraction in years leading up to the recession (Mian and Sufi 2011; Bhutta and Keys 2016). Aggregate housing wealth plunged by nearly $\$ 7$ trillion, wiping out all of the housing equity of nearly a quarter of mortgage borrowers (CEA 2012).

These "underwater" households that owed more on their house than its market value were often shut out of refinancing opportunities. Mortgages on homes with little or negative equity are considered unsecured credit for banks, triggering prohibitive capital charges if they were to be kept on the lending institution's balance sheet. This severely limited the availability of bank portfolio lending for mortgage refinancing. Similarly, the GSEs' charters explicitly prohibited securitizing loans with less than 20 percent equity in the absence of third-party credit enhancements.

Under normal market conditions, these enhancements are provided by private mortgage insurance (PMI) firms, which take the first-loss position on default-related costs. By typically covering $20 \%$ to $30 \%$ of the loan balance, PMIs enable the GSE to securitize loans with higher than 80 percent loan-to-value ratios while fulfilling their charter requirements. Far from providing stability during the Financial Crisis, PMI proved to be exposed to the catastrophic risk of nationwide housing declines (Bhutta and Keys 2018). Three of the eight active PMI companies went bankrupt, while others were forced to rescind existing policies and to rely on regulatory forbearance to stay in business. As a result, borrowers with insufficient equity in their homes could not rely on PMI policies to make them eligible for refinancing.

The final friction to refinancing arises in the presence of multiple loans collateralized by the same property. The practice of taking out junior lien loans, whether at the time of first mortgage origination to serve as de facto down payments (piggybacks) or as subsequent lines of credit, became fairly widespread in the years leading up to the financial crisis (Bhutta and Keys 2019). Having these junior lien loans can complicate refinancing of the first mortgage because of the legal feature that grants seniority to the oldest mortgage on the house in some (but not all) states. To retain its seniority upon refinancing, the first mortgage lender thus has to demand that the junior lien lender agree to subordinate its claim. Arming junior lenders with such blocking power can be expected to impede refinancing. Bond et al. (2017) exploit differences in state laws to show that for borrowers with limited equity that depend on junior lender cooperation, the blocking power of junior lenders lowers refinancing rates by 10 percent.

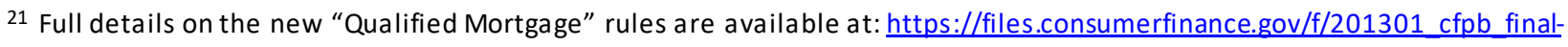
rule ability-to-repay.pdf. The so-called "DTI patch" made the Dodd-Frank limits on DTI less meaningful for GSE loans. 


\section{Policies to Ease Refinancing Frictions}

Although many refinancing frictions discussed in the previous section have always been present, the severity of the Great Recession generated a wide range of novel policy responses. Some of the policy actions directly expanded the already sizable government footprint in mortgage markets. Other actions centered on aligning incentives of private financial intermediaries to convert lower mortgage rates into actionable stimulus for households.

This section highlights some key lessons learned from the policymakers' experience. Among them is the utmost importance of institutional arrangements, the need to balance public interest and private actors' incentives, and the need for continuous refinement of policy parameters. Each of the policies described below - from GSE conservatorship to large-scale refinancing efforts - involved many choices that influenced the pass-through of monetary policy.

The first and, arguably, the most important policy action was the de facto nationalization of Fannie Mae and Freddie Mac in September 2008 after the two GSEs suffered severe credit losses and exhausted their capital. The resulting conservatorship structure made explicit the U.S. Government backing of GSE guarantees and allowed the GSEs to guarantee new loan issues, among them newly refinanced mortgages. The importance of this action in preserving the mortgage market is underscored in Figure 3 that shows a sharp spike in share of government-backed mortgages during the financial crisis.

With sharp house price declines pushing many homeowners into negative equity, government intervention became crucial for their ability to take advantage of dropping interest rates by refinancing. ${ }^{22}$ As discussed earlier, the GSE charter restrictions on purchasing high-LTV loans coupled with disarray in the PMI industry kept the GSEs from passing through lower interest rates to households. In response, the government launched the Home Affordable Refinancing Program (HARP) in 2009. Under HARP, the GSES were permitted to purchase refinance loans with LTV ratios up to 125 percent, with no requirement for obtaining new PMI. ${ }^{23}$

That said, the program was not explicitly intended to support monetary policy transmission, and instead was part of a broader financial rescue package to promote macroeconomic stabilization by mitigating foreclosures, and thus limited by design. ${ }^{24}$ Rather than follow the blueprint of the Great Depression when the federal government committed sizable capital to buying up and refinancing private mortgages through the Home Owners Loan Corporation (Rose 2011), HARP's reach was restricted to loans already guaranteed by the GSEs. Furthermore, the government tried to limit risks to taxpayers and to avoid the appearance of a bailout by only making non-delinquent (performing) mortgages eligible for HARP. Finally, as an

\footnotetext{
22 In private markets, lenders generally are unwilling to refinance underwater borrowers given the elevated risk of default losses when borrowers have no equity cushion. Moreover, the lack of outside refinancing options undermines competition that would incentivize lenders to refinance their existing borrowers. During the crisis period, the only notable source of refinancing for lowequity and underwater borrowers outside of government-based programs was about 50,000 low-equity refinances under the National Mortgage Servicing Settlement (Agarwal et al. 2017b).

23 If a loan already had PMI, no new coverage was required. If a mortgage did not carry PMI (was originated with at least a 20 percent equity), no new enhancement was required even if equity was below $20 \%$ at refinancing.

${ }^{24}$ At the time of HARP design, there was no firm empirical support for whether the MPC of underwater borrowers was necessarily higher than that of MBS investors, which contributed to its stated focus on foreclosure prevention.
} 
enticement to investors, eligible mortgages could only be refinanced through HARP once, which significantly lowered prepayment risk.

After HARP got off to a slow start, it became apparent that simply relaxing the LTV rules still left out many details that hindered both borrower and lender incentives to participate. As one example, HARP offered murky treatment of representation and warranties (R\&W) of refinanced mortgages. ${ }^{25}$ In particular, HARP allowed existing lenders to leave in place old $R \& W$, while requiring new lenders to face a stringent set of new R\&W conditions. This feature of the program had a chilling effect on competition.

Agarwal et al. (2017) use a variety of identification strategies to show that competitive frictions in HARP partly hampered the program's impact, reducing the take-up rate and annual savings by $10 \%$ to $20 \%$ with stronger effects among the most indebted borrowers, the key target of the program. This friction also had an effect on terms of refinanced loans. Amromin and Kearns (2016) use the discontinuity in HARP eligibility at LTV of 80 percent to find a sharp increase in the share of mortgages refinanced with the same lender at the eligibility threshold, as well as an increase in rate spread of about 11 basis points.

HARP 2.0, unveiled in November 2011, addressed some of the program's frictions but tilted the playing field even further in favor of existing lenders. ${ }^{26}$ Amromin and Kearns (2016) show that this nearly doubled the HARP spread to 20 basis. Only in January 2013 did the next set of HARP iterations partially addressed this distortion. Using a difference-in-differences approach around this date, Agarwal et al. (2017b) find a sharp improvement in interest rates on HARP mortgages and concurrent increase in refinancing rates. ${ }^{27}$

Unlike Fannie and Freddie, the FHA had allowed refinancing of its existing mortgages regardless of equity position for decades prior to the Great Recession. The streamlined refinancing program (SLR) did not require an updated appraisal, credit score, or even employment. However, faced with massive credit losses, the FHA changed its SLR requirements in September 2009. Now borrowers had to verify employment and were not allowed to roll upfront insurance and closing costs into a new loan without agreeing to a new appraisal. DeFusco and Mondragon (2019) show that these measures had a profoundly negative effect on the refinancing ability of FHA borrowers who were either unemployed or had little or no equity in their homes - the most vulnerable population insured by the FHA.

The FHA subsequently stopped requiring employment verification for SLR in June 2011 and in June 2012 and further increased the appeal of the program by effectively eliminating upfront insurance premiums. Since this change applied only to loans originated prior to 2009, Ehrlich and Perry (2017) are able to use a regression discontinuity framework to show a near doubling of refinancing volumes for eligible loans.

In sum, the post-crisis experience showed that policy actions can be effective in resolving some of the most severe cyclical frictions. However, even small policy details can be consequential, highlighting the need for policymakers' continuous learning and for their ongoing ability to implement necessary changes.

\footnotetext{
25 See footnote 20 for a description of R\&W. Amherst Mortgage Insight (2010) and Moody's Analytics (2010) provide details on frictions in the original HARP.

26 The revised HARP lowered upfront loan charges, allowed some solicitation by new lenders, and removed the LTV limit, among other things.

27 As of 2019:Q1, HARP refinanced 3.5 million mortgages, more than a million of which had LTV ratios in excess of 105 percent. See https://www.fhfa.gov/AboutUs/Reports/ReportDocuments/Refi 102019.pdf.
} 


\section{Refinancing, Mortgage Payment Size, and Consumption}

This section explores the micro- and macro-economic consequences of refinancing. While there are a number of impediments to refinancing, as discussed above, here we consider how refinancing affects household consumption and investment conditional on having refinanced.

Selection issues complicate the estimation of the causal effect of refinancing on consumption. Households must make an active decision to refinance, and this decision will reflect generally unobserved individual factors such as liquidity, time preferences, and financial literacy. Further complicating matters, variation across households in their marginal propensity to consume (MPC) may be correlated with these factors. For example, the financially savvy households that are more likely to refinance when rates drop may have relatively low MPCs.

Two recent papers exploit variation in eligibility for HARP refinancing to help circumvent these identification issues. Agarwal et al. (2017b) take advantage of the fact that only GSE-securitized loans were eligible for HARP, while similar but privately-securitized loans were not eligible. After confirming the sizable impact of HARP on refinancing in the eligible group, the study shows that treated borrowers increased their consumption of durables (autos) following refinancing with the strongest effects for the most indebted borrowers. The paper also uses the ex-ante share of HARP-eligible loans in a ZIP-code as an instrument to find that regions more exposed to HARP experienced relative increases in durable (autos) and non-durable (credit card spending) consumption. ${ }^{28}$

Abel and Fuster (2018) use a different strategy of looking within GSE-securitized loans and exploiting the fact that only borrowers with loans that were purchased by the GSEs before June 1, 2009 were eligible for HARP. They find that in response to refinancing through HARP, household balance sheets improve by shifting their composition away from high-cost credit card borrowing and into HELOC and auto loan debt, with about $20 \%$ of the amount of decreased mortgage payments going towards increased non-mortgage debt.

A related strand of research estimates the consumption effects of reductions in monthly mortgage payments due to downward interest rate resets on ARMs, which became more prevalent during the housing boom years (Figure 1). ARMs in the U.S. typically have initial fixed periods of 2, 3, 5, or 7 years, and then annually adjusting rates thereafter. As loans exited their fixed period in the crisis years, monthly payments declined sharply for many ARM borrowers. This identification strategy was initially introduced by Tracy and Wright (2016) and Fuster and Willen (2017) to show that payment size has a substantial effect on mortgage default. ${ }^{29}$ Complementing and extending these studies, DiMaggio et al. (2017) find that a 50 percent decrease in mortgage payments leads to a significant 35 percent increase in car purchases. The effect size is much higher for borrowers with lower incomes and less housing wealth whose liquidity constraints are likely relaxed by the reduction in monthly payments. ${ }^{30}$ These studies clearly demonstrate the countercyclical benefits of ARMs.

\footnotetext{
28 Agarwal et al. (2017) also find that regions with higher HARP exposure also saw a decline in foreclosure rates and a faster recovery in house prices.

${ }^{29}$ Countercyclical income support, such as extended unemployment insurance, has similarly been shown to lower defaults. Hsu, Matsa, and Melzer (2018) estimate that UI extensions during the Great Recession prevented 1.3 million foreclosures.

30 The authors further explore the impact of lower mortgage rates on regional economic activity. They find that regions with an ex ante higher share of outstanding ARMs in 2006 experience greater interest rate pass-through from 2007-2012. This greater pass-through to consumer is associated with lower default rates, less severe house price declines, increased consumption (auto
} 
Another key factor in borrowers' decision to refinance is the opportunity to simultaneously access accumulated home equity. In fact, households may refinance even when interest rates have not declined, purely to extract equity to fund an investment opportunity or to smooth consumption (Hurst and Stafford 2004; Chen, Michaux, and Roussanov 2020). But a drop in interest rates can further incentivize equity extraction, freeing up large amounts of cash for consumption and investment. Also, a decline in rates can boost equity extraction by easing borrowing constraints due to debt-payment-to-income limits (Greenwald 2018). Indeed, Bhutta and Keys (2016) document that the likelihood of extracting equity peaked in 2003 as mortgage rates fell to historic lows, with about $\$ 40,000$ of equity freed up on average. ${ }^{31}$ They estimate a strong effect of rate drops on the likelihood of equity extraction, especially in cities where house prices have been rising rapidly.

DiMaggio, Kermani, and Palmer (2018) and Beraja et. al. (2019) show that QE-induced mortgage rate declines spurred refinancing, equity extraction activity, and durable goods spending. However, the latter paper also emphasizes that this monetary stimulus was most effective in regions where the housing bust was least severe and thus where stimulus may have been least needed. ${ }^{32}$

How do borrowers use extracted equity? Canner, Dynan, and Passmore (2002) draw on a special survey of mortgage borrowers and find that the most common reported uses are: home improvements (35\%), paying off debts (26\%), consumer expenditures (16\%, including vehicles, education or medical expenses), and real estate or business investments (10\%). Earlier waves of the survey, examined by both Canner, Luckett, and Durkin (1990) and Brady, Canner, and Maki (2000), as well as work by Cooper (2010) using the PSID, find an overall similar distribution of uses.

Bhutta and Keys (2016) provide indirect evidence that extracted equity is likely used for consumption, as opposed to optimizing household balance sheets, by showing that extraction is associated with substantial increases in defaults on both mortgages and consumer loans. Both Beraja et al. (2019) and DiMaggio, Kermani, and Palmer (2020) show that equity extraction (and possibly pure refinancings) lead to more car purchases. ${ }^{33}$ Other related work, such as Lovenheim (2011), examines the usage of liquid housing wealth on other household expenditures, such as paying for college.

In countries that rely more on floating rate mortgages, such as the UK, Spain, and Italy, monetary policy transmission via mortgage markets is more automatic and immediate. For instance, Cumming and Dettling (2019) report that in the UK in 2008-2009, borrowers whose rates were floating saw their mortgage payments fall by $£ 1,000$ per quarter, a 42 percent near-instantaneous decline. Moreover, they show that stimulus via adjustable mortgages increased birth rates and, in contrast to the U.S., helped prevent a "baby bust" in the UK. Cloyne, Ferreira, and Surico (2020) also highlight that mortgage payments fall considerably more in the UK than in the US after a rate shock, while Hughson et al. (2016) and Floden et al. (2019) examine the transmission channel through the mortgage market in Australia and Sweden, respectively. See Calza, Monacelli, and Stracca (2013) for an international survey on the

purchases), and relatively more nontra dable employment growth. This result is especially compelling evidence of the importance of monetary policy and how it reaches the real economy through the mortgage market.

31 More generally, equity extraction as home prices boomed during the early 2000's contributed substantially to the growth in household debt (Mian and Sufi 2011; Bhutta 2015).

32 A similar conclusion is drawn in earlier work by Caplin, Freeman, and Tracy (1997).

33 Results in McCully, Pence, and Vine (2019) suggest that extraction may be used for down payments rather than substituting for auto loans. 
connections between mortgage finance system design and the strength and speed of monetary policy transmission.

It is worth noting, of course, that mortgage investors receive correspondingly lower interest income when households refinance. Thus, the aggregate effect of the refinancing channel on the economy depends on the relative MPCs by households vs. investors and bank shareholders. This point is emphasized more generally in Auclert (2019), who argues that a key channel of monetary expansions is through redistribution toward agents with higher MPCs. Additionally, Boyce, Hubbard, and Mayer (2012) estimate that during the housing bust, 14 percent of all mortgage-backed securities were held abroad, creating an additional incentive for domestic policy action.

\section{Path Dependence in Refinancing and Monetary Policy}

To this point, we have largely discussed the refinancing decision as static, but the dynamic aspects of both households' refinancing and the Federal Reserve's monetary policy actions deserve further scrutiny and yield additional insights into their interaction. For households, while the decision can be separated contract by contract (or call option by call option), the borrower's long-term goal should be to minimize lifetime interest payments and transaction costs. ${ }^{34}$ For investors, the market value of a mortgage depends on the likelihood of prepayment: Multiple recent refinancing waves should increase the expected duration of the new mortgages and thereby increase the value of their associated mortgage-backed securities.

A dynamic perspective helps to reconcile why an interest rate cut of a particular size may have a different impact on the macroeconomy in different settings. For example, Figure 6 shows the distribution of outstanding 30-year mortgage interest rates in 2006, 2012, and 2018. Whereas in $200694 \%$ of mortgages had ratesabove $5 \%$, by 2018 , after multiple refinancing waves, the median outstanding rate dropped to about $4 \%$, with only $17 \%$ of mortgage debt having rates above $5 \% .{ }^{35}$ As of March 2020, as the Federal Reserve aggressively eased in response to the COVID-19 pandemic, mortgage rates returned to the low levels of 2012, but a relatively low fraction of existing borrowers would appear to potentially benefit by refinancing (see Figures 3 and 4A). Both Berger et al. (2018) and Eichenbaum et al. (2018) provide macro models that support the view that the efficacy of monetary policy depends on the potential savings from an interest rate cut. The size of the pool of potential refinancers - those whose call option is sufficiently in the money - depends crucially on the past path of rates.

While the case for the importance of a dynamic framework for understanding the stimulative effects of monetary policy is persuasive, it is worth re-emphasizing that the largest response on consumption frequently comes not only from rate refinancing, but from cash-out refinancing and other equity extraction decisions. ${ }^{36}$ Even if homeowners have locked in low rates on their existing mortgages, they may nonetheless want to extract equity through cash-out refinancing, or extract through a home equity loan or line of credit (and avoid resetting their primary mortgage rate), when rates are relatively low (see

\footnotetext{
34 See Yang and Maris (1993) for a model that allows for borrowers to sequentially refinance.

35 The 2012 distribution offers yet another example of the importance of frictions: Even though the reference mortgage rate dropped to $4 \%$ by then, nearly $40 \%$ of mortgages had rates above $5.5 \%$.

36 Greenwald (2018) emphasizes the importance of equity extraction for monetary policy transmission.
} 
Figure 4). ${ }^{37}$ The interaction of interest rates and house prices in the context of dynamic models along these lines is thus an area worthy of further investigation. ${ }^{38}$

\section{Mortgage Design}

In this section, we briefly touch on an emerging literature that reimagines mortgage design in the U.S. in light of the lessons learned during the financial crisis. A starting point here is the recognition - among many economists, at least - of the shortcomings of the 30-year FRM and its role in exacerbating the crisis. The rigidity of this contract, while perhaps a boon to households during good times, became a serious drag during bad times, stifling monetary policy aimed at stimulating household consumption and preventing mortgage defaults (Calza, Monacelli, and Stracca 2013; Auclert 2019). Wong (2019) estimates that the effect of monetary policy on consumption would be substantially enhanced by moving to a variable-rate mortgage structure.

To be sure, advocating alternative mortgage contracts will face an uphill battle against the broader public's love of the 30-year self-amortizing fixed-rate mortgage. Risk aversion seems to play a central role in borrowers' preference for FRMs, such that ARMs are chosen only when the FRM-ARM spread widens substantially (Coulibaly and Li 2009). Importantly, the lack of ARM use may suggest an excessive fear of rising rates and too little appreciation for the risk of recessions - a bias that, if true, policy ought to address.

Notably, fear of ARMs seems to have grown since the crisis, perhaps reflecting the unfounded "explodingARM" narrative of the crisis (Foote, Gerardi, and Willen 2012). Amortizing (hybrid) ARMs are eligible for purchase by the GSEs and can be insured by the FHA - and thus receive the same credit risk subsidy as FRMs - yet there has been scant use of ARMs since the crisis (see Figure 1). ${ }^{39}$ Pricing for ARMs does not seem to fully explain this trend. The spread between long and short mortgage rates-historically a good predictor of ARM use (Koijen et al. 2009; Moench, Vickery, and Aragon 2010) - widened considerably at times after 2009, but ARM use remained subdued. ${ }^{40}$

Recognizing the strengths of both FRMs and ARMs, Eberly and Krishnamurthy (2014) propose a convertible mortgage: a FRM with a one-time option to convert into a floating rate mortgage. In followup work, Guren, Krishnamurthy and McQuade (2018) build a general equilibrium model to evaluate the benefits of the "EK convertible" mortgage, versus pure ARMs and pure FRMs, and find that the EK

\footnotetext{
37 Low rates can also facilitate moving to a new home, which can be thought of as another form of equity extraction, promoting mobility and labor reallocation.

38 Beraja, Fuster, Hurst, and Vavra (2019) look at variation in refinancing that arise from regional differences in house price movements and resulting home equity, while Bhutta and Keys (2016) specifically examine the interaction between rates and prices driving extraction decisions during the early 2000's.

39 FRMs may enjoy a slight subsidy not available to ARMs, stemming from FRMs eligibility for securitization through the agency "to-be-announced" (TBA) forward market, which can improve liquidity and pricing (Vickery and Wright 2013).

40 ARMs are more prevalent in the jumbo market than in the conforming market (Moench, Vickery, and Aragon 2010). This could reflect supply-side effects as banks and credit unions often hold jumbo mortgages in portfolio and thus may not offer long-term fixed rate contracts. It could also reflect demand-side effects as jumbo borrowers may be more price sensitive and financially savvy (Bhutta, Fuster, and Hizmo 2019).
} 
mortgage provides most of the benefits of an ARM during a downturn, while also providing significant protection against the risk of rising rates. ${ }^{41}$

Starting borrowers with an FRM - and with no obligation to ever convert to floating rate - is an intriguing idea, and may help to endear this contract to borrowers who fear rising rates. That said, the conversion option will make this contract more expensive than a standard 30-year FRM, by about 17 basis points (as estimated by Guren et al.). The key upside, though, is the considerable protection offered in a downturn (see our earlier discussion in Section 5 on the consumption effects of downward-adjusting ARMs).

Another potential downside of an EK-type contract is that households may only convert to an ARM during a downturn when absolutely necessary to avoid default. This type of behavior could impede monetary policy transmission relative to an all-ARM economy during a downturn. A useful exercise for future research would be to evaluate ARMs that have rate adjustment caps, which limit households' exposure to rate risk, but can still provide some automatic downward adjustment during crises. ${ }^{42}$ Finally, there are likely to also be benefits from other forms of indexation that take into account local economic conditions (Piskorski and Seru 2018), including labor income risk. Future research should additionally consider contracts that give individual borrowers some payment optionality to deal with idiosyncratic income volatility (Piskorski and Tchistyi 2010; Mayer, Piskorski, and Tchistyi 2013). That said, it is important to note that in periods of widespread economic disruption, the large-scale exercise of such options may place considerable pressure on the housing finance system. For example, extensive use of mortgage forbearance during the early stages of the COVID-19 pandemic threatened a liquidity crisis for mortgage servicers who must replace borrower payments to investors. A well-designed system should be robust to such systemic events, perhaps with better-capitalized servicers and/or investors sharing in the risk of payment disruptions.

\section{Applying Lessons Learned and Questions for Future Research}

The residential mortgage market represents a critical channel for monetary policy to stimulate household consumption. In this paper, we review the literature on the existence and importance of the refinancing channel, describe the frictions that inhibit the functioning of this channel, assess policy responses to these frictions, and examine potential innovations to reduce frictions. In essence, these frictions represent de facto prepayment penalties that function as barriers to refinancing. Further research is needed to estimate how much prepayment speeds would change if borrowers were highly sophisticated and/or transaction costs were sharply reduced, and what impact this change in prepayment patterns would have on mortgage rates.

We document the prevalence of refinancing over the 2000s, highlighting the spikes in refinancing in 2003 and 2012, and the differences between cash-out and rate refinancing between high- and low-score borrowers. Despite these spikes, many mortgage-holders whose refinancing option appears to be "in the money" fail to take advantage. We discuss both behavioral and cyclical impediments to refinancing. As

\footnotetext{
41 Piskorski and Tchistyi (2017) also build an equilibrium model to study alternative mortgage contracts, and highlight potential welfare benefits of ARMs relative to FRMs. Another recent proposal focuses on helping borrowers more quickly pay down equity, but maintain fixed payment contracts (Passmore and von Hafften 2020)

42 ARMs with a 15 or 20 year term, as proposed by Oliner, Peter, and Pinto (2018), may help reduce the risk of payment shock and could be another type of mortgage to consider.
} 
a growing literature has documented dispersion in interest rates and ineffective search, more analysis of heterogeneous search costs affecting the refinancing decision would enrich our understanding of impediments to refinancing.

Our review of the literature underlines the complicated interactions between monetary policy and house prices in determining the stimulative effect on household consumption. For instance, the 2003 refinancing boom was accentuated by rising house prices in many metro areas, which encouraged cashout refinancing. Although this spike in refinancing reduced the pool of potential rate refinancers in subsequent years, house price appreciation led many homeowners, especially lower-credit-score households, to extract equity. Such households did so primarily through cash outs, while higher-score households tapped into equity with home equity loans or lines of credit. Further examination of the interplay between home prices and interest rates, along with innovative contracts to reduce transaction costs, is a promising direction for further research

Our exploration of policies to reduce frictions in policy transmission emphasizes the numerous barriers to ex-post renegotiation in the mortgage market, and the limitations of federal policy for loans not backed by government agencies. Issues surrounding institutional barriers, representations and warranties, and needlessly restrictive underwriting requirements all hindered refinancing activity, at a time when government action could have been more sweeping and forceful in reducing mortgage interest rates. This research points also to the potential distorting effect of federal policy on competition in the mortgage market, as HARP disproportionately favored incumbent lenders.

A potential solution to avoiding these frictions is to encourage more borrowers to take up adjustable rate or hybrid-ARM products, which would automatically reset downward when the Fed cuts rates. For instance, few young homebuyers stay in their "starter" home for more than ten years, and thus are unlikely to benefit from the full protection of a 30-year FRM. The benefits of existing hybrid contracts, as well as other flexible contract types that have been recently proposed, should be evaluated in general equilibrium models. More research should examine why ARM take-up rates are so low after the financial crisis, and identify ways that the FHA and other lenders could help educate first-time buyers on such alternatives to the 30-year fixed-rate mortgage. Given the continued predominance of the 30-year FRM, having a HARP-like program permanently in place to be automatically "triggered" in a crisis may ease further frictions.

The lessons learned in the midst of an economic emergency enrich our understanding of market forces and policy mechanisms, hopefully leading to better outcomes and more effective monetary policy transmission in subsequent downturns. At the time of preparing this manuscript, the COVID-19 pandemic has brought about an unprecedented disruption in economic activity. The immediate housing policy response to the pandemic consisted of streamlined forbearance actions by Congress and the GSEs. These actions have largely avoided the pitfalls of requiring time-consuming and conflicting documentation requirements that marred early version of programs in the previous financial crisis. Prompt forbearance has the potential to provide substantial liquidity support to households in the near term and mitigate delinquency and housing price pressures. However, these actions create multiple stresses elsewhere in the housing finance ecosystem, as forborne cash flows must be absorbed by someone other than households.

As of April 2020, the monetary policy response to the pandemic included a rapid decrease in policy rates to the zero lower bound (Figure 3), as well as a wide range of programs to provide liquidity and direct 
lending to financial markets, firms, and municipalities. Unlike the financial crisis, transmission of traditional policy actions to households is impeded by income shortfalls, not insufficient home equity. It is also affected by capacity and liquidity constraints in mortgage origination, some of which stem from large-scale forbearance actions. In the short run, monetary policy transmission has been also impeded by turbulence in functioning of mortgage finance markets, which required the Fed to conduct large-scale asset purchases to restore stability and allow (partial) convergence of primary and secondary mortgage rates.

Although the forward path of the economy is highly uncertain, future policies will likely have to address conversion of forbearance actions into modifications, as well as enable access to longer-term relief through refinancing. Once again, conventional and unconventional monetary policy tools will be deployed alongside actions by housing finance regulators and private market participants to provide economic support to households and enable their access to mortgage finance. The success of these policy responses will depend on expanding the arsenal of policy tools given the limits of the zero lower bound, developing a coordinated housing and mortgage market response across policy-making bodies, and internalizing the lessons and insights provided by research examined in this review.

\section{LITERATURE CITED}

Abel J, Fuster A. 2018. How do mortgage refinances affect debt, default, and spending? Evidence from HARP. Staff Rep. 841, Fed. Reserve Bank, New York

Adelino M, Gerardi K, Willen PS. 2013. Why don't lenders renegotiate more home mortgages?

Redefaults, self-cures and securitization. J. Monet. Econ. 60(7):835-53

Acharya, V. V., Richardson, M., Van Nieuwerburgh, S., \& White, L. J. (2011). Guaranteed to fail: Fannie Mae, Freddie Mac, and the debacle of mortgage finance. Princeton University Press.

Agarwal S, Ben-David I, Yao V. 2016. Systematic mistakes in the mortgage market and lack of financial sophistication. J. Financ. Econ. 123(1):42-58

Agarwal S, Amromin G, Ben-David I, Chomsisengphet S, Evanoff DD. 2011. The role of securitization in mortgage renegotiation. J. Financ. Econ. 102(3):559-78

Agarwal S, Amromin G, Ben-David I, Chomsisengphet S, Piskorski T, Seru A. 2017a. Policy intervention in debt renegotiation: evidence from the Home Affordable Modification Program. J. Political Econ. 125(3):654-712

Agarwal S, Amromin G, Chomsisengphet S, Landvoigt T, Piskorski T, et al. 2017b. Mortgage refinancing, consumer spending, and competition: evidence from the Home Affordable Refinancing Program. NBER Work. Pap. 21512

Agarwal S, Driscoll JC, Laibson DI. 2013. Optimal mortgage refinancing: a closed-form solution. J. Money 
Credit Bank. 45(4):591-622

AgarwalS, Rosen RJ, Yao V. 2019. Why do borrowers make mortgage refinancing mistakes? Manag. Sci. 62(12):3494-509

Alexandrov, A., \& Koulayev, S. (2018). No shopping in the U.S. mortgage market: Direct and strategic effects of providing information. Consumer Financial Protection Bureau Office of Research Working Paper, (2017-01).

Allen J, Clark R, Houde JF. 2014. Price dispersion in mortgage markets. J. Ind. Econ. 62(3):377-416

Amherst Securities. 2010. Frictions in the HARP refi process. Amherst Mortgage Insight

Amromin G, Huang J, Sialm C, Zhong E. 2018. Complex mortgages. Rev. Finance 22(6):1975-2007

Amromin G, Kearns C. 2014. Access to refinancing and mortgage interest rates: HARPing on the importance of competition. Work. Pap. 2014-25, Fed. Reserve Bank, Chicago

Andersen S, Campbell JY, Nielsen KM, Ramadorai T. 2015. Inattention and inertia in household finance: evidence from the Danish mortgage market. NBER Work. Pap. 21386

Archer WR, Ling DC, McGill GA. 1996. The effect of income and collateral constraints on residential mortgage terminations. Reg. Sci. Urban Econ. 26(3/4):235-61

Badarinza C, Campbell JY, Ramadorai T. 2018. What calls to ARMs? International evidence on interest rates and the choice of adjustable-rate mortgages. Manag. Sci. 64(5):2275-88

Bajo E, Barbi M. 2018. Financial illiteracy and mortgage refinancing decisions. J. Bank. Finance 94:279-96

Beraja M, Fuster A, Hurst E, Vavra J. 2019. Regional heterogeneity and the refinancing channel of monetary policy. Q. J. Econ. 134(1):109-83

Berger D, Milbradt K, Tourre F, Vavra J. 2018. Mortgage prepayment and path-dependent effects of monetary policy. NBER Work. Pap. 25157

Bernanke BS, Reinhart VR, Sack BP. 2004. Monetary policy alternatives at the zero bound: an empirical assessment. Brookings Pap. Econ. Activity, Brookings Inst., Washington, DC

Bhutta N. 2015. The ins and outs of mortgage debt during the housing boom and bust. J. Monet. Econ. 76:284-98

Bhutta N, Fuster A, Hizmo A. 2019. Paying too much? Price dispersion in the U.S. mortgage market. Work. Pap., Board Gov. Fed. Reserve Syst./Swiss Natl. Bank

Bhutta N, Keys B. 2016. Interest rates and equity extraction during the housing boom. Am. Econ. Rev. 106(7):1742-74

Bhutta N, Keys B. 2018. Eyes wide shut? The moral hazard of mortgage insurers during the housing boom. NBER Work. Pap. 24844 
Bond P, Elul R, Garyn-Tal S, Musto D. 2017. Does Junior inherit? Refinancing and the blocking power of second mortgages. Rev. Financ. Stud. 30(1):211-44

Boyce, A., Hubbard, G., Mayer, C., \& Witkin, J. (2012). Streamlined refinancings for up to 14 million borrowers. Unpublished working paper. Columbia University, New York, NY.

Brady PJ, Canner GB, Maki DM. 2000. The effects of recent mortgage refinancing. Fed. Reserve Bull. 86(7):441-50

Brainard, W. C., \& Tobin, J. (1968). Pitfalls in financial model building. The American Economic Review, 58(2), 99-122.

Bucks B, Pence K. 2008. Do borrowers know their mortgage terms? J. Urban Econ. 64(2):218-33

Calza A, Monacelli T, Stracca L. 2013. Housing finance and monetary policy. J. Eur. Econ. Assoc. 11(Suppl. 1):101-22

Campbell JY. 2006. Household finance. J. Finance 56(4):1553-604

Campbell JY. 2014. Mortgage market design. Rev. Finance 17(1):1-33

Campbell JY, Cocco JF. 2003. Household risk management and optimal mortgage choice. Q. J. Econ. 118(4):1499-94

Canner GB, Dynan K, Passmore W. 2002. Mortgage refinancing in 20001 and early 2002. Fed. Reserve Bull. 88(12):469-81

Canner GB, Luckett CA, Durkin TA. 1990. Mortgage refinancing. Fed. Reserve Bull. 76(8):604-12

Caplin A, Freeman C, TracyJ. 1997. Collateral damage: refinancing constraints and regional recessions. J. Money Credit Bank. 29(4):497-516

CEA (Counc. Econ. Advis.). 2012. Economic report of the president: stabilizing and healing the housing market. Rep., CEA, Washington, DC

Chen H, Michaux M, Roussanov N. 2020. Houses as ATMs? Mortgage refinancing and macroeconomic uncertainty. J. Finance 75(1):323-75

Cloyne J, Ferreira C, Surico P. 2020. Monetary policy when households have debt: new evidence on the transmission mechanism. Rev. Financ. Stud. 87(1):102-29

Cochrane JH, Piazzesi M. 2002. The Fed and interest rates-a high-frequency identification. Am. Econ. Assoc. Pap. Proc. 92(2):90-95

Coulibaly B, Li G. 2009. Choice of mortgage contracts: evidence from the Survey of Consumer Finances. RealEstate Econ. 37(4):659-73

Cook, T., \& Hahn, T. (1989). The effect of changes in the federal funds rate target on market interest rates in the 1970s. Journal of Monetary Economics, 24(3), 331-351. 
Cooper, D. 2010. Did easy credit lead to overspending? Home equity borrowing and household behavior in the early 2000s. FRB of Boston Public Policy Discussion Paper, (09-7).

Cumming, F., \& Dettling, L. (2020). Monetary Policy and Birth Rates: The Effect of Mortgage Rate PassThrough on Fertility. FEDS Working Paper.

D'AmicoS, King TB. 2013. Flow and stock effects of large-scale Treasury purchases: evidence on the importance of local supply. J. Financ. Econ. 108(2):425-48

DeFusco AA, Mondragon J. 2020. No job, no money, no refi: frictions to refinancing in a recession. J. Finance. In press

Deng Y, Quigley JM. 2012. Woodhead behavior and the pricing of residential mortgages. Work. Pap., Lusk Cent. Real Estate, Univ. South. Calif., Los Angeles

Di Maggio M, Kermani A, Keys BJ, Piskorski T, Ramcharan R, et al. 2017. Interest rate pass-through: mortgage rates, household consumption, and voluntary deleveraging. Am. Econ. Rev. 107(11):355088

Di Maggio, M., Kermani, A., \& Palmer, C. J. (2020). How quantitative easing works: Evidence on the refinancing channel. The Review of Economic Studies, 87(3), 1498-1528.

Dokko J, Keys BJ, Relihan L. 2019. Affordability, financial innovation, and the start of the housing boom.

Drechsler I, Savov A, Schnabl P. 2018. Banking on deposits: maturity transformation without interest rate risk. Work. Pap., NYU, New York

Driscoll JC, Judson RA. 2013. Sticky deposit rates. Staff Work. Pap. 2013-80, Fed. Reserve Board Finance Econ. Discuss. Ser., Washington, DC

Dunn KB, McConnell JT. 1981. Valuation of GNMA mortgage-backed securities. J. Finance 36(3):599-616

Eberly J, Krishnamurthy A. 2014. Efficient credit policies in a housing debt crisis. Brookings Pap. Econ. Activity, Brookings Inst., Washington, DC

Ehrlich G, Perry J. 2017. Do large-scale refinancing programs reduce mortgage defaults? Evidence from a regression discontinuity design. Work. Pap. 2015-06, Congr. Budg. Off., Washington, DC

Eichenbaum M, Rebelo S, Wong A. 2018. State dependent effects of monetary policy: the refinancing channel. NBER Work. Pap. 25152

Farber, H. S., \& Valletta, R. G. (2015). Do extended unemployment benefits lengthen unemployment spells? Evidence from recent cycles in the US labor market. Journal of Human Resources, 50(4), 873909.

Flodén, M., Kilström, M., Sigurdsson, J., \& Vestman, R. (2019). Household debt and monetary policy: Revealing the cash-flow channel. Riksbank Research Paper Series, (166), 18-4. 
Foote $\mathrm{CL}$, Gerardi KS, Willen PS. 2012. Why did so many people make so many expost bad decisions? The causes of the foreclosure crisis. NBER Work. Pap. 18082

Frame WS, White LJ. 2005. Fussing and fuming over Fannie and Freddie: how much smoke, how much fire? J. Econ. Perspect. 19(2):159-84

Fuster A, Goodman L, Lucca D, Madar L, Molloy L, Willen P. 2013. The rising gap between primaryand secondary mortgage rates. Econ. Policy Rev., Fed. Reserve Bank, New York

Fuster A, Vickery J. 2015. Securitization and the fixed-rate mortgage. Rev. Financ. Stud. 28(1):176-211

Fuster A, Willen PS. 2010. \$1.25 trillion is still real money: some facts about the effects of the Federal Reserve'smortgage market investments. Public Policy Discuss. Pap., Fed. Reserve Bank, Boston

Fuster A, Willen PS. 2017. Payment size, negative equity, and mortgage default. Am. Econ. J. Econ. Policy 9(4):167-91

Gagnon JE, Raskin M, Remache J, Sack B. 2010. Large-scale asset purchases by the Federal Reserve: Did they work? Staff Rep. 441, Fed. Reserve Bank, New York

Gerardi K, Herkenhoff K, Ohanian LE, Willen P. 2018. Can't pay or won't pay? Unemployment, negative equity, and strategic default. Rev. Financ. Stud. 31(3):1089-131

Gertler M, Karadi P. 2015. Monetary policy surprises, credit costs, and economic activity. Am. Econ. J. Macroecon. 7(1):44-76

Gilchrist S, López-Salido D, Zakrajšek E. 2015. Am. Econ. J. Macroecon. 7(1):77-109

Green J, Shoven JB. 1986. The effects of interest rates on mortgage prepayments. J. Money Credit Bank. 18(1):41-59

Green RK, LaCour-Little M. 1999. Some truths about ostriches: who doesn't prepay their mortgages and why they don't. J. Hous. Econ. 8(3):233-48

Green RK, Wachter SM. 2005. The American mortgage in historical and international context. J. Econ. Perspect. 19(4):93-114

Greenwald DL. 2018. The mortgage credit channel of macroeconomic transmission. Res. Pap. 5184-16, MIT Sloan Sch. Bus., Cambridge, MA

Guren AM, Krishnamurthy A, McQuade TJ. 2018. Mortgage design in an equilibrium model of the housing market. NBER Work. Pap. 24446

Gurun, U. G., Matvos, G., \& Seru, A. (2016). Advertising expensive mortgages. The Journal of Finance, 71(5), 2371-2416.

Hancock D, Passmore W. 2011. Did the Federal Reserve's MBS purchase program lower mortgage rates? J. Monet. Econ. 58(5):498-514 
Hanson SG, Stein JC. 2015. Monetary policy and long-term real rates. J. Financ. Econ. 115(3):429-48

Hsu JW, Matsa DA, Melzer BT. 2018. Unemployment insurance as a housing market stabilizer. Am. Econ. Rev. 108(1):49-81

Hughson, H., La Cava, G., Ryan, P., \& Smith, P. 2016. The Household Cash Flow Channel of Monetary Policy| Bulletin-September Quarter 2016. Reserve Bank of Australia Bulletin, (September).

Hurst E, Keys BJ, Seru A, Vavra J. 2016. Regional redistribution through the US mortgage market. Am. Econ. Rev. 106(10):2982-3028

Hurst E, Stafford F. 2004. Home is where the equity is: mortgage refinancing and household consumption. J. Money Credit Bank. 36(6):985-1014

Jaffee, D. M. 2015. An international perspective for mortgage market reform. J. Money, Credit and Banking, 47(S1), 59-67.

Jiang W, Nelson AA, Vytlacil E. 2014. Liar's loan? Effects of origination channel and information falsification on mortgage delinquency. Rev. Econ. Stat. 96(1):1-18

Johnson EJ, Meier S, Toubia O. 2018. What's the catch? Suspicion of bank motives and sluggish refinancing. Rev. Financ. Stud. 32(2):467-95

Justiniano A, Primiceri GE, Tambalotti A. 2017. The mortgage rate conundrum. NBER Work. Pap. 23784 Keys BJ, Pope DG, Pope JC. 2016. Failure to refinance. J. Financ. Econ. 122(3):482-99

Koijen RSJ, Van Hemert O, Van Nieuwerburgh SV. 2009. Mortgage timing. J. Financ. Econ. 93(2):292-324

Krishnamurthy A, Vissing-Jorgensen A. 2011. The effects of quantitative easing on interest rates: channels and implications for policy. Brookings Pap. Econ. Activity, Brookings Inst., Washington, DC

Kuttner KN. 2001. Monetary policy surprises and interest rates: evidence from the Fed funds futures market. J. Monet. Econ. 47(3):523-44

Lea M. 2010. International Comparison of Mortgage Product Offerings. Washington, DC: Res. Inst. Hous. Am.

Lovenheim, M. F. (2011). The effect of liquid housing wealth on college enrollment. Journal of Labor Economics, 29(4), 741-771.

Mayer C, Morrison E, Piskorski T, Gupta A. 2014. Mortgage modification and strategic behavior: evidence from a legal settlement with Countrywide. Am. Econ. Rev. 104(9):2830-57

Mayer C, Piskorski T, Tchistyi A. 2013. The inefficiency of refinancing: why prepayment penalties are good for risky borrowers. J. Financ. Econ. 107(3):694-714

McCully, B. A., Pence, K. M., \& Vine, D. J. 2019. How Much Are Car Purchases Driven by Home Equity Withdrawal?. Journal of Money, Credit and Banking, 51(5), 1403-1426. 
Mian A, Sufi A. 2011. House prices, home equity-based borrowing, and the US household leverage crisis. Am. Econ. Rev. 101(5):2132-56

Moench E, Vickery J, Aragon D. 2010. Why is the market share of adjustable-rate mortgages so low? Curr. Issues Econ. Finance 16(8):1-11

Nakamura E, Steinsson J. 2018. High-frequency identification of monetary non-neutrality: the information effect. Q. J. Econ. 133(3):1283-330

Oliner S, Peter T, Pinto EJ. 2018. The wealth building home loan. Work. Pap. 2017-23, Am. Enterp. Inst., Washington, DC

Passmore, W. (2005). The GSE implicit subsidy and the value of government ambiguity. Real Estate Economics, 33(3), 465-486.

Passmore, W., \& Sherlund, S. M. (2019). FHA, Fannie Mae, Freddie Mac and the Great Recession. Real Estate Economics.

Passmore SW, Von Hafften AH. 2020. Financing affordable and sustainable homeownership with fixedCOFI mortgages. Reg. Sci. Urban Econ., 80, 103392

Pavlov, A. D. (2001). Competing risks of mortgage termination: who refinances, who moves, and who defaults?. The Journal of Real Estate Finance and Economics, 23(2), 185-211.

Piskorski T, Seru A. 2018. Mortgage market design: lessons from the Great Recession. Brookings Pap. Econ. Activity, Brookings Inst., Washington, DC

Piskorski T, Seru A, Vig V. 2010. Securitization and distressed loan renegotiation: evidence from the subprime mortgage crisis. J. Financ. Econ. 97(3):369-97

Piskorski T, Tchistyi A. 2010. Optimal mortgage design. Rev. Financ. Stud. 23(8):3098-140

Piskorski T, Tchistyi A. 2017. An equilibrium model of housing and mortgage markets with statecontingent lending contracts. NBER Work. Pap. 23452

Rose, J. D. (2011). The incredible HOLC? Mortgage relief during the Great Depression. Journal of Money, Credit and Banking, 43(6), 1073-1107.

Rose J. 2019. Short-term residential mortgage contracts in American economic history. Work. Pap., Fed. Reserve Bank, Cleveland, $\mathrm{OH}$

Scharfstein D, Sunderam A. 2016. Market power in mortgage lending and the transmission of monetary policy. Harvard Business School working paper.

Stanton R. 1995. Rational prepayment and the valuation of mortgage-backed securities. Rev. Financ. Stud. 8(3):677-708

TracyJ, Wright J. 2016. Payment changes and default risk: the impact of refinancing on expected credit 
losses. J. Urban Econ. 93:60-70

Urban Inst. 2013. Housing Finance at a Glance: A Monthly Chartbook. Washington, DC: Hous. Finance Policy Cent., Urban Inst.

Vickery J, Wright J. 2013. TBA trading and liquidity in the agency MBS market. Econ. Policy Rev., Fed. Reserve Bank, New York

Wong A. 2019. Refinancing and the transmission of monetary policy to consumption. Working paper. http://www.arlene-wong.com/research.

Woodward, S. E., \& Hall, R. E. (2012). Diagnosing consumer confusion and sub-optimal shopping effort: Theory and mortgage-market evidence. American Economic Review, 102(7), 3249-76.

Yang TL, Maris BA. 1993. Mortgage refinancing with asymmetric information. Real Estate Econ. 21: 481510 
Figure 1: FRM Share of Annual Issuance of Purchase Mortgages and Outstandings, 1998-2018

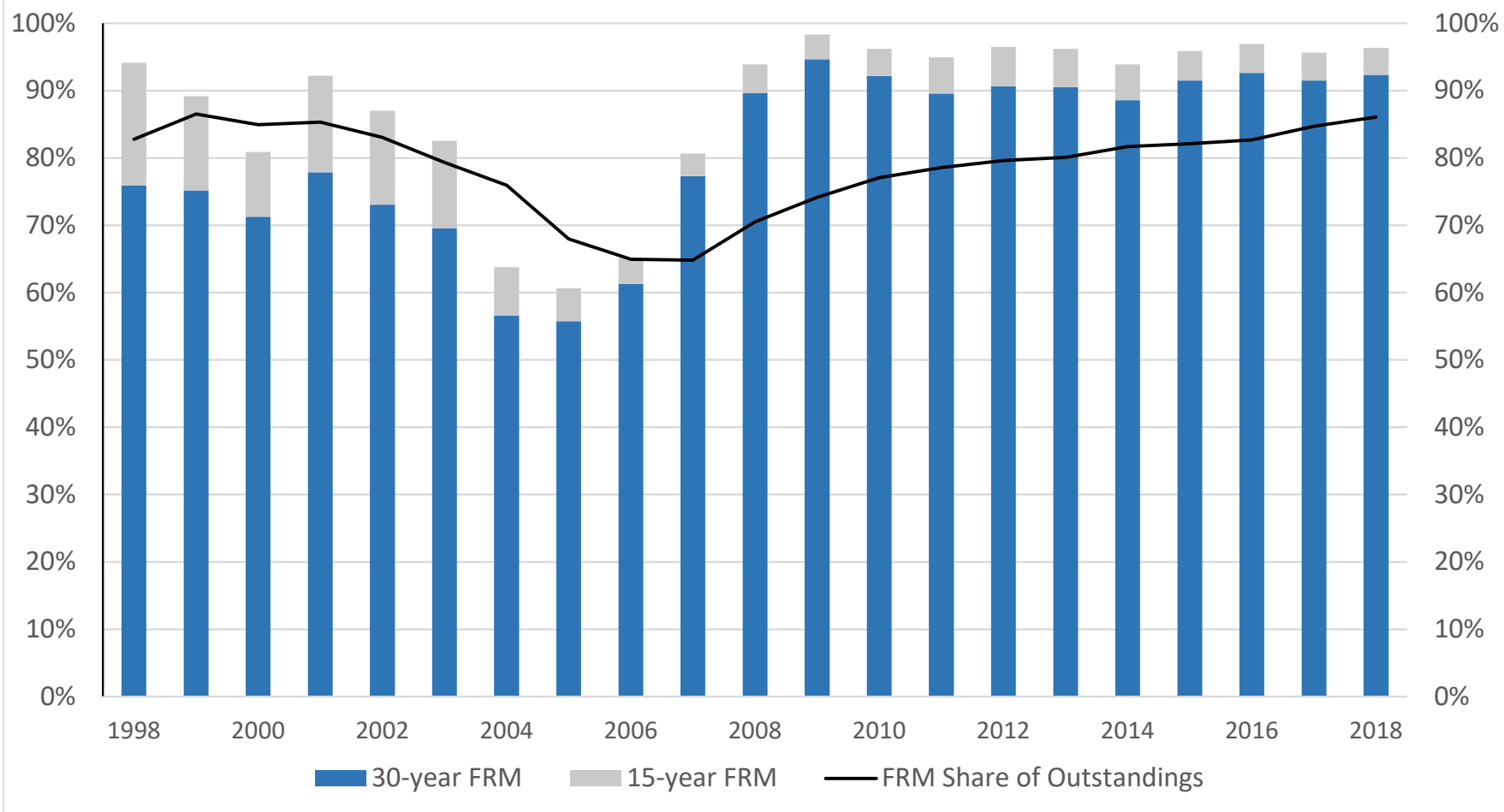

Source: Authors tabulations from Black Knight McDash Data.

Notes: Based on $5 \%$ sample of McDash data; includes only single-family, first lien, owner-occupied mortgages. Bars show fractions, by count, of home-purchase originations that are 30-year and 15-year (or higher, but less than 30-year) FRM. Black line shows the fraction, by dollar volume, of all outstanding mortgage debt that is fixed rate with at least a 15 -year term. The McDash data are based on data from the largest mortgage servicers. Coverage of the mortgage market has increased over time, ranging from about $25 \%$ in 1998 to over $50 \%$ since 2006 . 
Figure 2: Government-backed and Private Mortgage Securitization Issuance Shares, 2001-2019

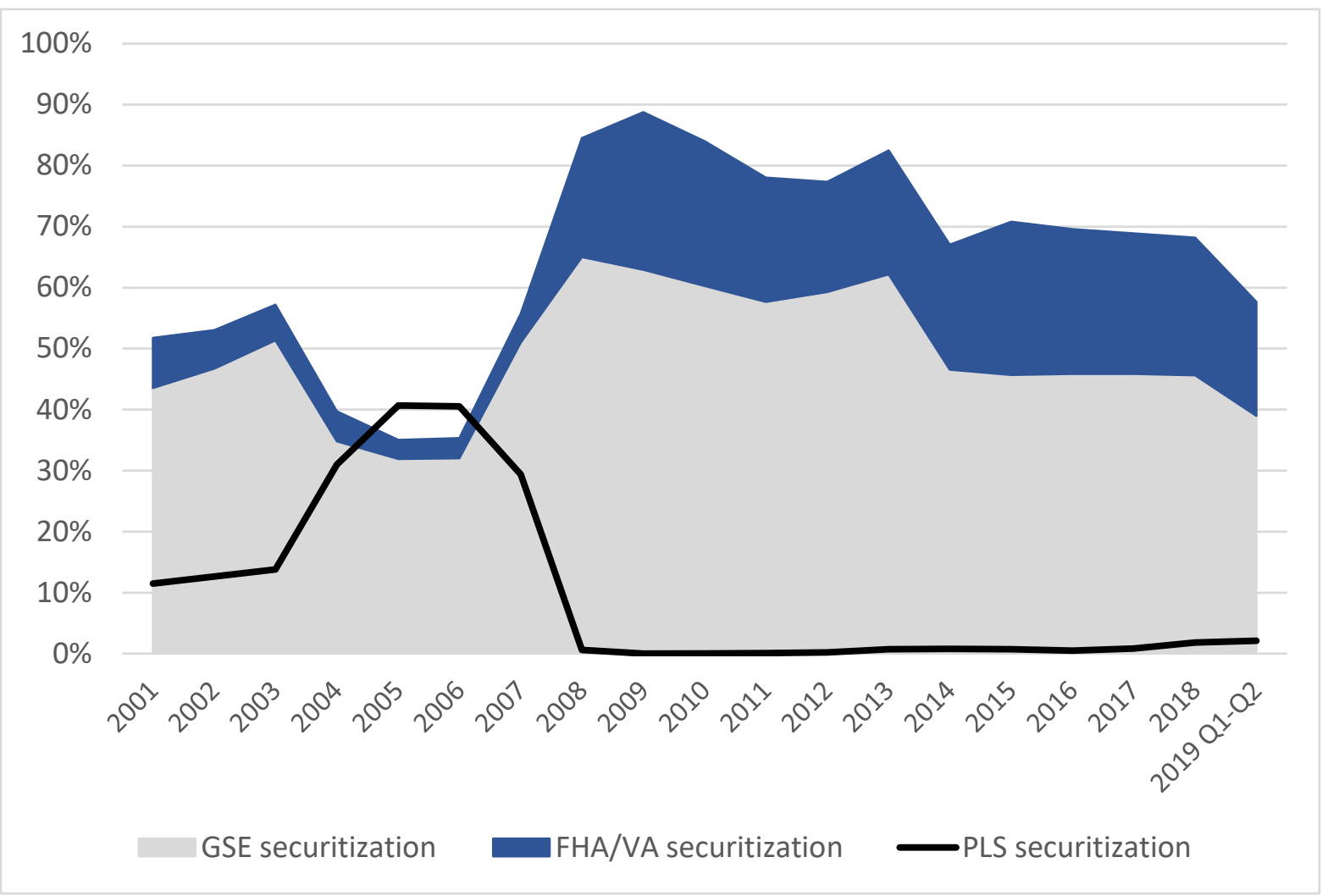

Source: Urban Institute and Inside Mortgage Finance

Note: Residual issuance is attributed to mortgages held on bank portfolios 
Figure 3: Key Interest Rates, 2000-2020

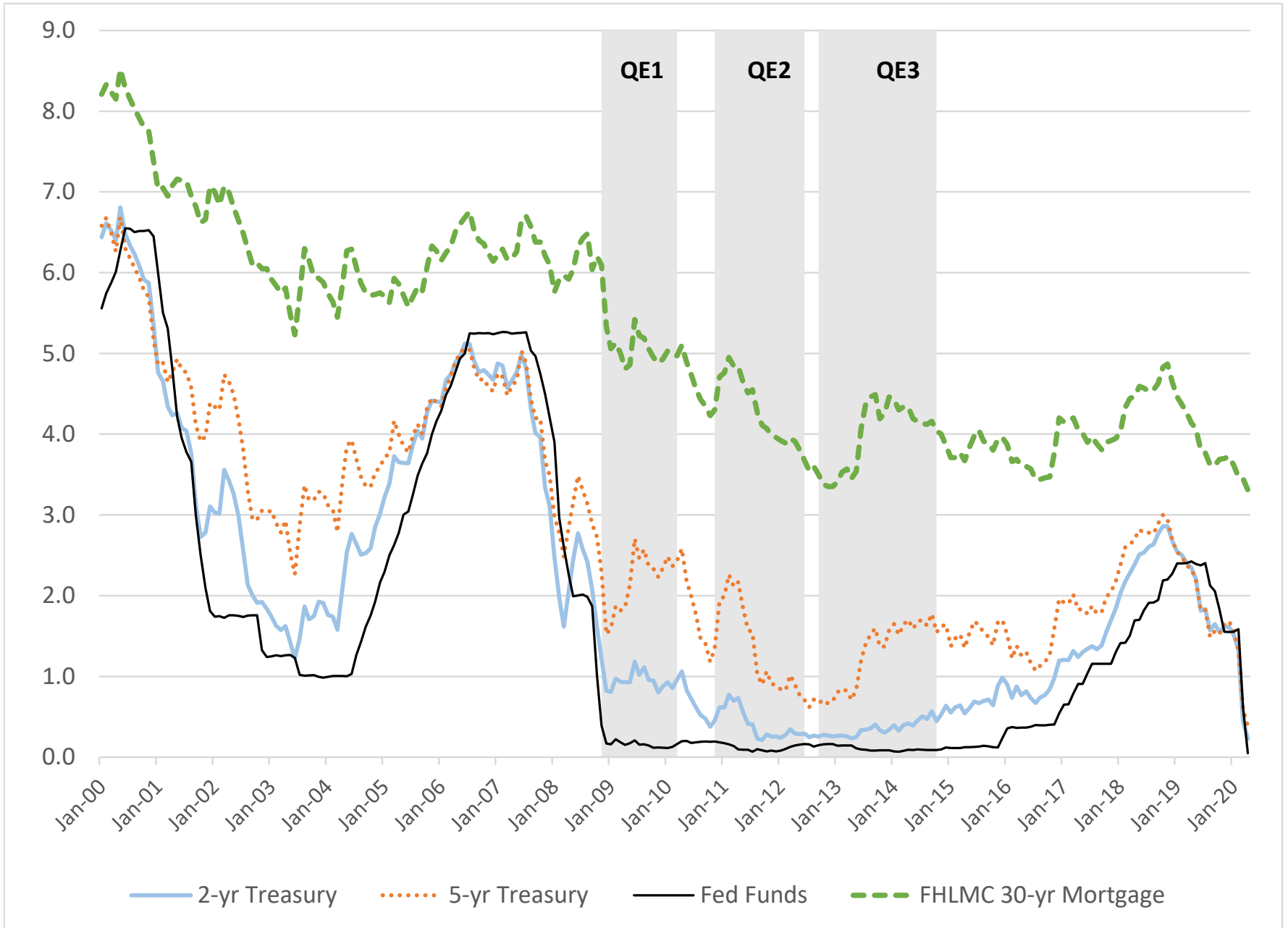

Source: Haver Analytics. Interest rate data are monthly averages, through April, 2020. 
Figure 4: Refinancing, Equity Extraction and Rate Distribution over Time, 2000-2018

Panel A. Share of FRMs with rates at least $100 \mathrm{bp}$ above prime rate

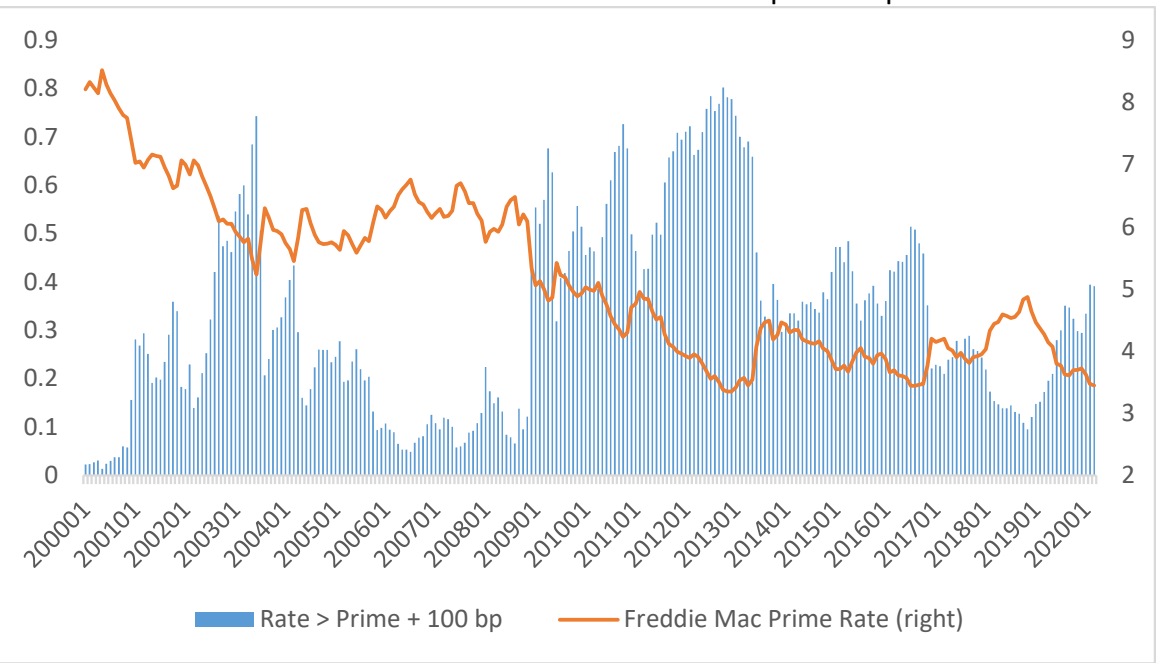

Panel C. Rate refinancing over time, by credit score

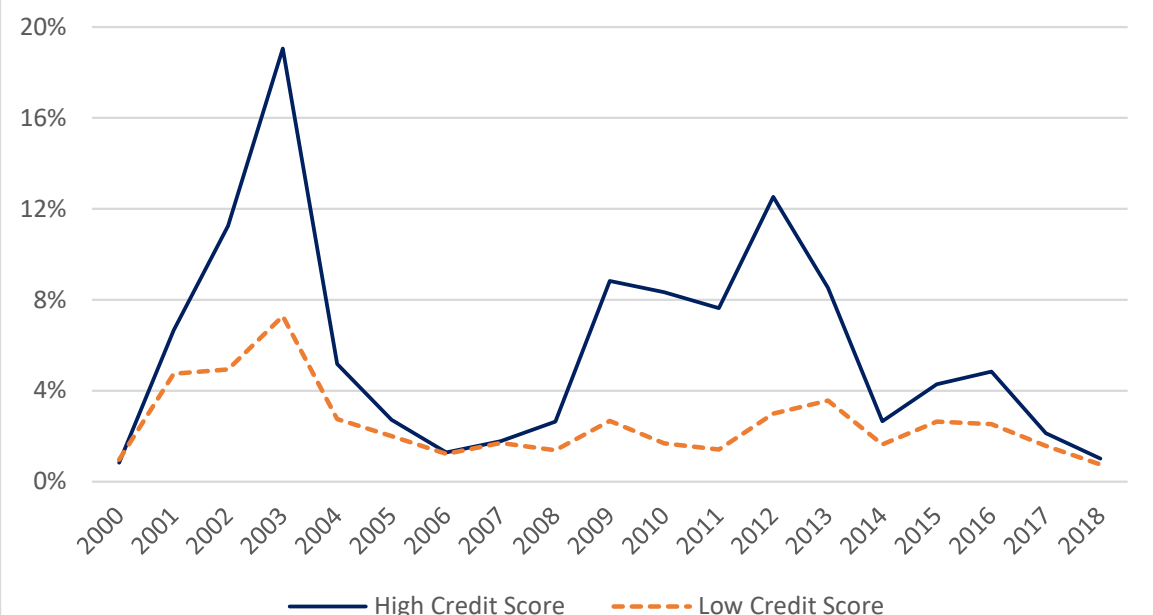

Panel B. Refinancing and equity extraction over time

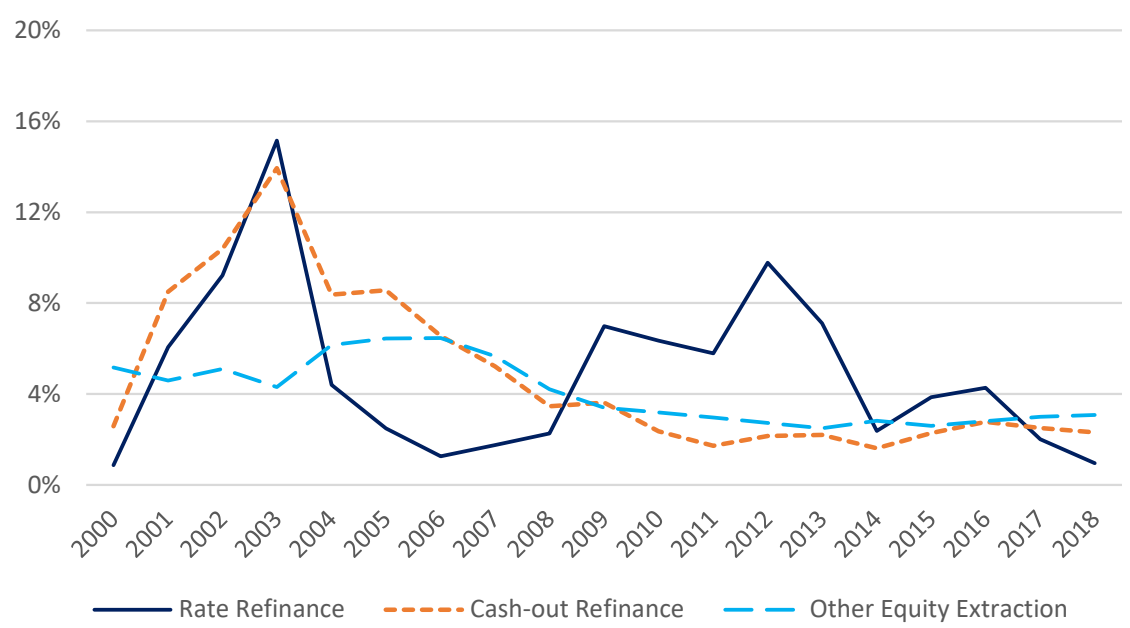

Panel D. Cash out refinancing over time, by credit score

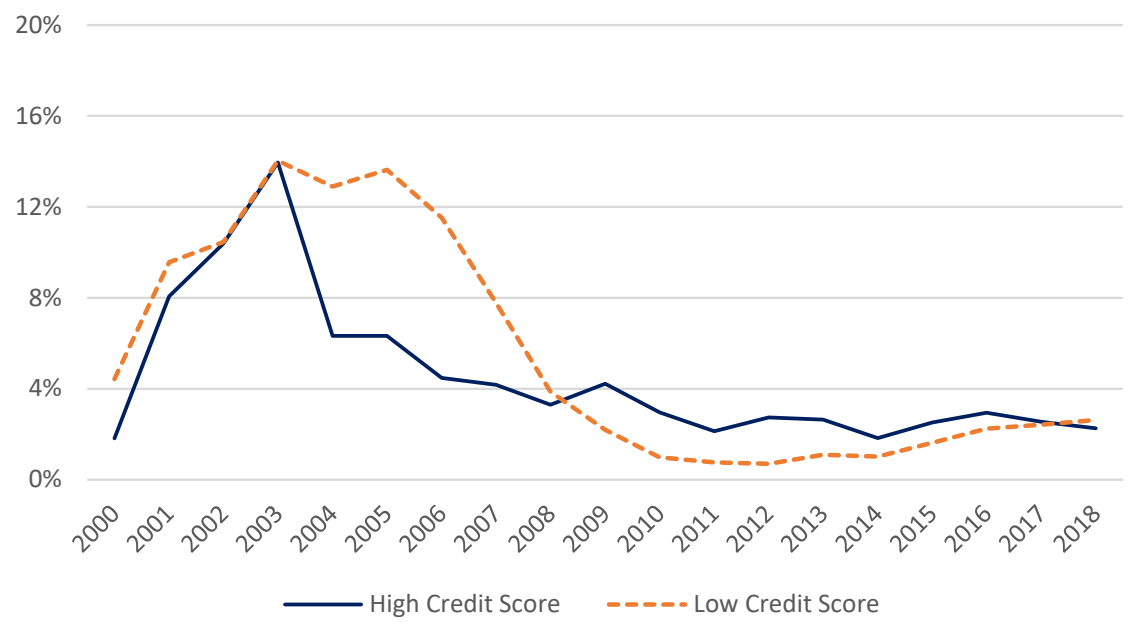

Sources: Authors' calculations from Black Knight McDash Data Jan 2000-Mar 2020 (Panel A) and FRBNY Consumer Credit Panel/Equifax Data (CCP; Panels B, C, D)

Notes: See Figure 1 notes for information about the McDash data. CCP is a $5 \%$ sample of consumers with a credit file and valid Social Security Number, and provides detailed credit data at a quarterly frequency. The statistics here are based on yearly samples of individuals with at least $\$ 5000$ in mortgage debt at the start of the year on just one property (inferred from their number of and size of mortgages) and who do not move during the year. "Rate refinance" is the share of sample borrowers who open a new first lien mortgage during the year and their mortgage debt does not grow by more than $5 \%$. "Cash-out refinace" is the share who open a new first lien mortgage during the year and their total mortgage debt grows by more than $5 \%$. "Other equity extraction" is the share whose mortgage debt grows by at least 5\%, through a new second lien or by drawing on an existing HELOC. Credit score is the Equifax 3.0 Risk Score, measured at the start of the year; "high" is a score above 680 . Observations are weighted to account for the higher likelihood of sampling joint mortgages. For computational reasons, we use a $2 \%$ sample of the $\mathrm{CCP}$, resulting in a $0.1 \%$ sample of the population with a credit record. 
Figure 5: Refinancing and Mortgage Rates, 1990-2017

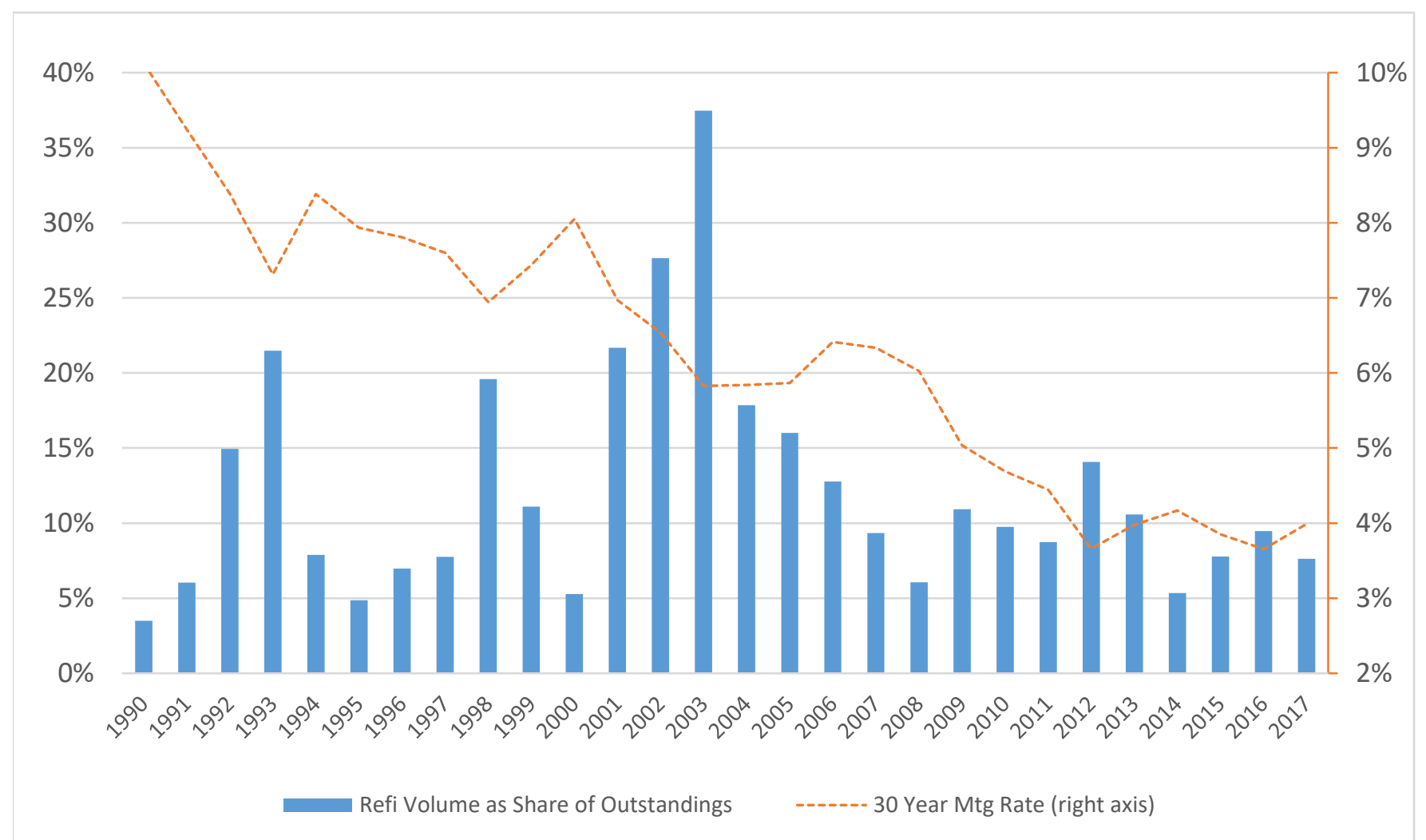

Sources: Home Mortgage Disclosure Act (HMDA) data; Federal Reserve Financial Accounts of the U.S.; Freddie Mac Primary Mortgage Market Survey

Notes: Blue bars show the dollar volume of all refinance originations for 1-4 family properties reported in the HMDA data, divided by outstanding mortgage debt from the Financial Accounts as the fourth quarter of the previous year. 
Figure 6: Distribution of Interest Rates on Oustanding 30-year FRM Contracts

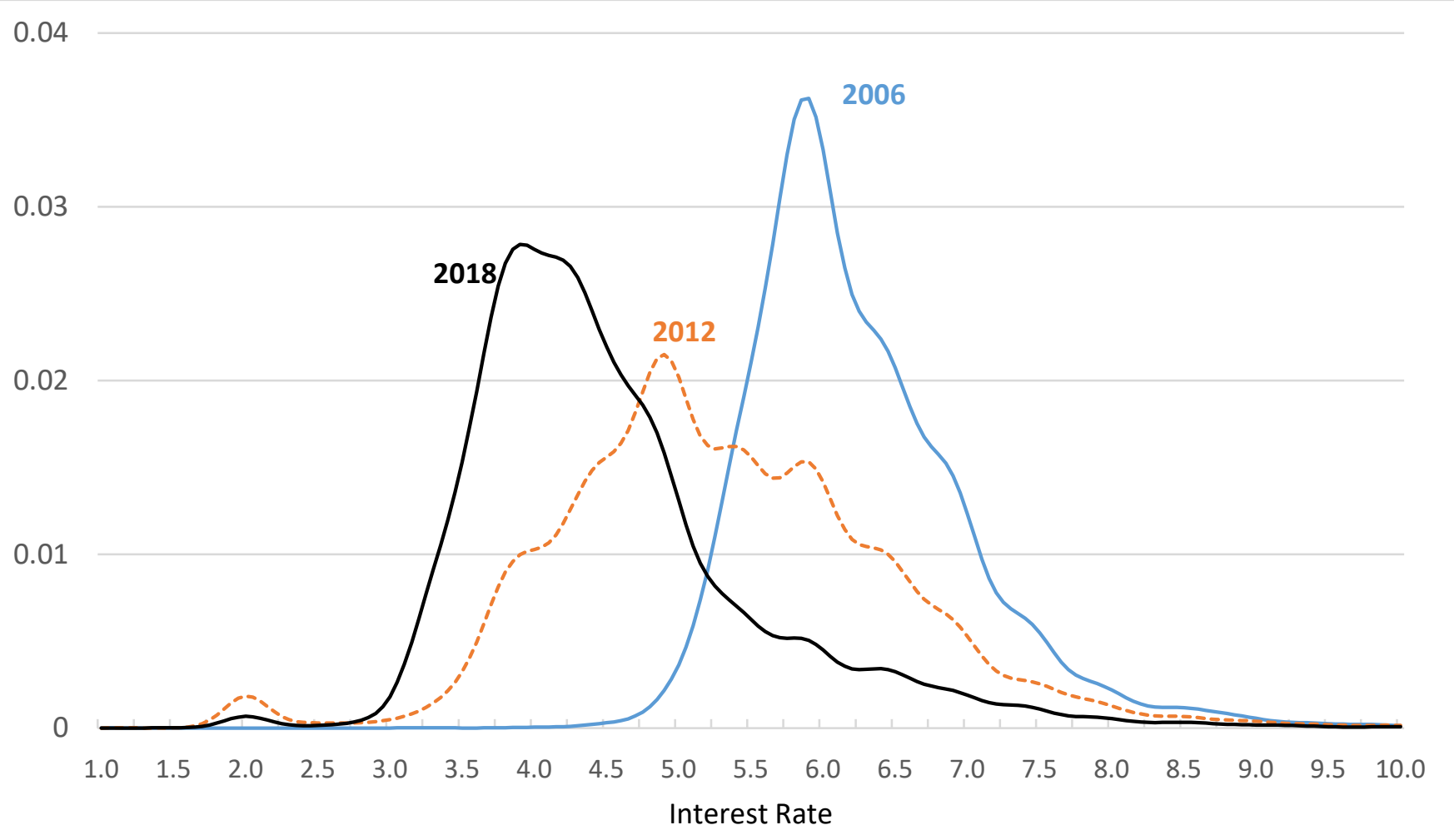

Source: BlackKnight McDash Data

Notes: Kernel densities are estimated on a value-weighted sample of 30-year fixed rate mortgages. See notes to Figure 1 for additional information about the McDash data. 